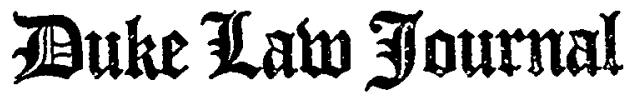

\begin{tabular}{lll}
\hline VOLUME 1973 & JUNE & NUMBER 2 \\
\hline
\end{tabular}

\section{OPINION LETTERS AND PROFESSIONALISM $\dagger$}

\author{
JoHN P. FrEeman*
}

Lawyers who serve corporate chients recognize that for sheer shock value the ultimate resolution of the Securities and Exchange Commission's (SEC) National Student Marketing Corp. litigation ${ }^{1}$ may never match the effect achieved by the Commission simply through filing the complaint. The high drama achieved by the SEC's action is, of course, attributable to its decision to allege violations of the securities laws ${ }^{2}$ on the part of not just the usual coterie of accountants and insiders, but also by the law firms of White \& Case and Lord, Bissell \& Brook and by certain of their lawyers indi-

$\dagger$ A substantial portion of this article deals with securities laws violations alleged by the Securities and Exchange Commission in SEC v. National Student Marketing Corp., Civ. Action No. 225-72 (D.D.C., filed Feb. 3, 1972). The reader should bear in mind that the SEC's factual allegations and legal theories have not as yet stood the test of an adversary proceeding on the merits. Nothing said in this article is meant to suggest that there is truth in the SEC's charges of misconduct by the defendants. Dame.

* Member, Ohio Bar. B.B.A., 1967; J.D., 1970, University of Notre

This article was written in connection with course work for a graduate securities law seminar which the author attended while a Fellow at the University of Pennsylvania Law School Center for Study of Financial Institutions. The author is indebted to the Director of the Center, Professor Robert H. Mundheim, for his invaluable counsel and assistance, and also thanks the practitioners and students who participated in the seminar for their comments and suggestions. The views expressed are his own.

1. SEC v. National Student Marketing Corp., Civ. Action No. 225-72 (D.D.C., filed Feb. 3, 1972). For the text of the complaint, see [1971-1972 Transfer Binder] CCH FED. SEC. L. REP. T 93,360, at 91,913 (D.D.C. 1972).

2. In the course of four claims for relief, the SEC asserts violations by various defendants of section 17(a) of the Securities Act of 1933, 15 U.S.C. $\S 77 q(a)$ (1970); section $10(\mathrm{~b})$ of the Securities Exchange Act of 1934 , id. $\$ 78 \mathrm{j}(\mathrm{b})$ (1970), and rule 10b-5 thereunder, 17 C.F.R. $\$ 240.10 \mathrm{~b}-5$ (1972); and sections 13 and 14(a) of the Securities Exchange Act of 1934, 15 U.S.C. $\$ \S 78 \mathrm{~m}$ and $78 \mathrm{n}(\mathrm{a})$, and "rules and regulations thereunder." The substantive allegations that are material to this article are detailed at pp. 419-21 infra. 
vidually, together with a lawyer who is a sole practitioner. ${ }^{3}$

Almost as startling as the identity of the cast of defendants is the ineasure of relief deinanded-entry of injunctions permanently restraining the defendant attorneys froin violating the securities laws. ${ }^{4}$ Besides making any future securities law violation by an enjoined defendant a contempt of court, entry of the relief prayed for would furnish the Commission with grounds for sanctioning the defendant attorneys under rule 2(e) of the Commission's Rules of Practice. Among the penalties that could be imposed thereunder is suspension of the privilege of appearing or practicing before the Commission. ${ }^{\circ}$ The drastic effect of such a sanction on a law firm's corporate practice is easily seen.

This article addresses one of the major issues raised by the SEC in its charges against the defendant attorneys: the accountability of

3. The defendants: National Student Marketing Corp. (NSMC); Cortes W. Randell, President, Chief Executive Officer and Director of NSMC; John G. Davies, Vice President, General Counsel and a Director of NSMC; James F. Joy, Executive Vice President and a Director of NSMC; Bernard J. Kurek, Controller of NSMC; Roger O. Walther, Director and former officer of NSMC; Peat, Marwick, Mitchell \& Co. (PMM); Anthony M. Natelli, partner in charge of PMM's Washington, D.C., office; Joseph Scansaroli, former PMM accountant and Assistant Controller of NSMC; White \& Case; Marion Jay Epley, III, partner of White \& Case; Robert A. Katz, attorney for purchasers of Compujob, Inc., from NSMC; Cameron Brown, formerly President of Interstate National Corp. (INC), now President and Chief Executive Officer of NSMC; Paul E. Allison, formerly Director of INC and of INC's successor which is a wholly owned subsidiary of NSMC; William J. Bach, same capacities as Allison; Robert P. Tate, formerly INC's Chairman and a former Director of INC's successor; Lord, Bissell \& Brook; Max E. Meyer, Lord, Bissell partner and former INC board member; Louis F. Schauer, Lord, Bissell partner.

Summary judgment was entered in favor of Allison, Bach and Tate in SEC v. National Student Marketing Corp., [1972-1973 Transfer Binder] CCH FEd. SEC. L. REP. If 93,820 , at 93,552 (D.D.C. 1973). The basis for the granting of summary judgment with respect to these defendants was that entry of the permanent injunction requested by the SEC would not further the public interest. Each of the three had resigned all director or corporate insider positions held and would not be expected to occupy such positions in the future. See id. at 93,563.

4. The injunctive relief requested has been termed "broad enough to cause nightmares whenever a professional's opinion is sought," BNA SEC. REG. \& $I$. REP. No. 138, at A-3 (1972); and it has been noted that requests for injunctive relief of the type sought by the Commission are usually "reserved for repeated or notorious violators of the law." Karmel, Attorneys' Securities Law Liabilities, 27 Bus. LAw. 1153, 1155 (1972). For a general discussion of the framework for equitable actions by the SEC, see Mathews, SEC Civil Injunction Actions 1 \& 11,5 REv. SEC. REg. 949, 969 (1972).

5. 17 C.F.R. $\$ 201.2(\mathrm{e})$ (1972). For a general discussion of rule 2(e), see Comment, SEC Disciplinary Rules and the Federal Securities Laws: The Regulation, Role and Responsibilities of the Attorney, 1972 DUKE L.J. 969.

6. 17 C.F.R. $\$ 202.2(\mathrm{e})(3)(1972)$. 
a lawyer for his opinion letters. The SEC's allegations and theories of recovery based upon opinions rendered by the defendant attorneys are considered in conjunction with a more general analysis of counsel's exposure for his opinion letters at common law and under the securities laws. Following that discussion, attention is given to an annotated set of guidelines drafted to assist lawyers in fulfilling their legal and professional responsibilities in the rendition of opinion letters. To lend some perspective to those analyses, the initial segment of the article briefly examines the modern phenomenon of the expanding constitutencies of the busimess manager and the lawyer who advises him.

\section{The LaWyer and His Corporate Client}

Just as it is readily apparent that the close working relationship between the bar and its busmess clientele has been a vastly useful and profitable one for both sides, it is clear that there are also dangers inherent in this symbiotic existence. Some of these dangers were pointed out by a group of able jurists during the 1920's and 1930's. Operating as a sort of "Distant Early Warning System," commentators such as Chief Justice William Howard Taft, ${ }^{7}$ Adolph A. Berle ${ }^{8}$ and Chief Justice Harlan Stone $e^{9}$ openly wondered whether, in striving to meet the demands of its corporate clients, a large seginent of the bar was not sacrificing some of its own character and integrity-its soul-not to mention its independence of thought and action. Chief Justice Stone phrased his views especially forcefully:

Steadily the best skill and capacity of the profession has been drawn into the exacting and highly specialized service of business and finance. At its best the changed system has brought to the command of the business world loyalty and a superb proficiency and technical skill. At its worst it has made the learned profession of an earlier day the obsequious servant of business, and tainted it with the morals and manners of the market place in its most anti-social manifestations. In any case we must concede that it has given us a Bar . . . whose energy and talent for public service and for bringing the law into harmony with changed conditions have been largely absorbed in the advanceinent of the interests of clients. ${ }^{10}$

The answer to Stone's broadside was delivered by Robert

7. See Taft, Legal Ethics, 1 Boston U.L. Rev. 233 (1921).

8. See Berle, The Modern Legal Profession, in IX EncYlopedia of the Soctal. SCIENCES 340 (1933).

9. See Stone, The Public Influence of the Bar, 48 HARv. L. Rev. 1 (1934).

10. Id. at 7. 
Swaine. Writing in $1949,{ }^{11}$ Swaine branded Stone's charge that the profession had become the "obsequious servant of business" as "inteinperate and exaggerated,"12 pointing out that the profession "has conducted itself with standards of morals and manners fully abreast of the morals and manners of the times; indeed usually ahead of them."13 Swaine nevertheless acknowledged that the closeness of the relationship between the legal profession and its business clients had bred some dubious practices. In particular, Swaine questioned the propriety of allowing an attorney in substance to become his own client through acting as a client's director or officer, ${ }^{14}$ and he observed that

it must be conceded that professional service to a single corporate client long continued contains a real threat to the lawyer's independence of thought, or at least of expression . . . . Loyalty to the client is a fundamental tenet of our profession. Where the linits of such loyalty are to be drawn is often a difficult question. ${ }^{15}$

Few would quarrel with Swaine's observations that client loyalty is a "fundamental tenet of our profession." For the lawyer who serves business interests, it may be difficult to identify just who the "client" is, however. Is the client: (1) management; (2) the board of directors; (3) the sliareholders; (4) all of the above; or (5) none of the above? ${ }^{16}$ This question is not so easily answered by a

11. Swaine, The Impact of Business on the Profession: An Answer to Critics of the Modern Bar, 35 A.B.A.J. 89 (1949).

12. Id. at 171 .

13. Id.

14. Id. at 170. Swaine's discomfort concerning the practice was highlighted by his claim that most corporate lawyers would be "greatly relieved" if lawyers were barred from serving as directors of their clients by a canon of ethics. Id. As was pointed out in an article written in 1956 by Martin Mayer, Swaine's "intensely effective answer" to Chief Justice Stone's criticism was remembered well by the profession, but his call for a canon outlawing acceptance of board positions with client firms by lawyers was soon forgotten. Mayer, Keepers of the Business Conscience, HARPER's MagazInE, Feb., 1956, at 50, 56. The efficacy of the practice criticized by Mr. Swaine is increasingly being called into question these days. See EXPANDINg Responsibilities UNDER THE Securities Acts TRANSCRIPT 166-68 (S. Goldberg ed. 1973); PLI, How To Go Public 310 (1971) (remarks of Prof. Donald E. Schwartz); Hoffman, Gradations in Liability, 27 Bus. LAw. 173, 176-77 (Special Issue Feb., 1972); Lefkowitz, The Attorney-Client Relationship and the Corporation, 14 Corp. Prac. Commentator 21 (1972); Loss, The Opinion, 24 Bus. Law. 527, 529 (1969). Cf. Marco v. Dulles, 169 F. Supp. 622 (S.D.N.Y. 1959), where it was noted that

acts [of a lawyer] as a director cannot be separated from his acts as a member of the firm who were [sic] general counsel for the corporation. The line between the two is entirely too fine to permit the professional obligation as a lawyer and the fiduciary obligation as a director to be placed in conveuient separate boxes. Id. at 631 .

15. Swame, supra note 11 , at 171.

16. According to the Code of Professional Responsibility, the answer is plain 
lawyer who works on a day-to-day basis with the corporation's executives, sits on the corporation's board, and regularly prepares and files documents with the SEC for submission to shareholders.

Apart from the always troublesome "who is your client" question, the modern business lawyer, not unlike the corporate manager lie advises, finds his professional environment increasingly complicated by a changing corporate scene. There was not always sucl confusion. In the bygone days of the moguls it was clear enough for the businessman that being a part of the management team meant serving the interests of the stockholders, and the raison d'être of the corporation's legal counsel was service to management. Those dark ages never knew appellations sucli as Ralph Nader; class action; ecology; Title VII; rule 10b-5; Pomerantz, Levy, Haudek \& Block; products liability or BarChris Construction Corporation. In those times judges did not say things like "a defective security should be no different from a defective product. Both carry dangerous consequences for the unsuspecting consumer."17 Why, it seems like only yesterday that a "defective product" was called a "lemon" and a "consumer" was just someone who used things up.

What has happened is that the times have clianged. . Responsibilities that were never recognized previously have now come into view. The obligations of corporate manageinent no longer can be viewed as running solely to the entity's ownership interest; instead,

enough: (5) none of the above. Ethical Consideration 5-18 tells us that:

A lawyer employed or retained by a corporation or similar entity owes his allegiance to the entity and not to a stockholder, director, officer, employee, representative, or other person connected with the entity. ABA CODE OF PROFEsSional RESPONSIBILITY AND CANONS OF Judicial ETHics, ETHICAL CONSIDERATION 5-18, at 20 (1971).

This guidance is rather meaningless in a specific context, a point demonstrated by the conflict arising when a corporation seeks to assert the attorneyclient privilege against its own shareholders. See Garner v. Wolfinbarger, $280 \mathrm{~F}$. Supp. 1018 (N.D. Ala. 1968) (holding corporation could not assert privilege against stockholders in suit charging mismanagennent), vacated, 430 F.2d 1093 (5th Cir. 1970) (ordering evidentiary hearing as to availability of privilege on facts presented), cert. denied, 401 U.S. 974 (1971), on remand, [1972-73 Transfer Binder] CCH FED. SEC. L. REP. If 93,600 (N.D. Ala. 1972) (rejecting assertion of privilege after hearing). The initial Garner holding was followed in Fischer v. Wolfinbarger, 45 F.R.D. 510 (W.D. Ky. 1968) (where the court noted that "[a] corporate entity acts only for its stockholders ...." Id. at 511). See also Federal Sav. \& Loan Ins. Corp. v. Fielding, 343 F. Supp. 537, 547-48 (D. Nev. 1972) (indicating that "the corporation is the client"); Kaplan, Conflicts of Interest in Corporate Law Practice, in ThIRD ANNUAL INSTITUTE ON SECURITIES REgulation 231, 234-37 (1972).

17. Black \& Co. v. Nova-Tech, Inc., 333 F. Supp. 468, 472 (D. Ore. 1971) (The phrases quoted were prefaced by the important words: "For jurisdictional purposes ...."). 
management finds itself answerable to a host of different groups, including its employees, its customers and the public at large. Coupled with this expansion of management's constituencies is one of the leading developments of the 1960's - the threat to management of personal and professional humiliation by reason of individual liability for misdeeds in the conduct of business matters. ${ }^{18}$ These phenoinena of an increasingly complex business world have served to make corporate managers ever more dependent on purveyors of legal advice. Attorneys' views carry more clout than they used to because clients need attorneys more. And as attorneys come to be idealized as the "due diligence men"19 and the "corporate conscience,"20 they must expect that the changing times will require of them a stricter accountability for their actions. ${ }^{21}$

Just as is the case with corporate nnanagement, these ideas of increased accountability and broadening responsibilities mean that the legal profession must now begin to cope with hitherto unrecog-

18. The impact on corporations of what has been called "the legal explosion" is discussed in Canth, The "Legal Explosion" Has Left Business Shell-shocked, FORTUNE, April, 1973, at 65. The significance of business management's expanding constituencies and increasing vulnerability to charges of misconduct has received the attention of the bar. E.g., Proceedings, ABA Nat'l Institute, Corporations Under Attack, in 28 Bus. LAW. 1 (Special Issue 1973); Proceedings, ABA Nat'l Institute, Officers' and Directors' Responsibilities and Liabilities, in 27 Bus. LAW. 1 (Special Issue Feb., 1972).

19. You represent the company. Who represents the outside directors? There used to be some talk at these panels that the outside directors should get together and hire a lawyer or financial adviser or somebody called the "due diligence man." The "due diligence man" would sit with the company lawyers, exercising due diligence 12 hours a day, looking over their shoulders, reporting back to his clients. That has not caught on, because I think everybody feels the "due diligence man" is already there. He is the company's lawyer. PLI, Protectivg tHE CoRPoRATE OFFICER AND DIRECTOR FROM LIABILITY 70 (1970) (remarks of Alan Applebaum).

20. Panel Discussion, The Corporate Conscience and the Corporate Bar, 26 Bus. LAW. 959 (1971) (focusing on the corporate lawyer's conscience). A different use of the phrase appears in the context of boards of directors. Professor Myles Mace points this out in his sprightly analysis of what directors can doand what they end up doing. M. MACE, Directors: MYTH AND ReAlity 26-27 (1971). See also Mayer, supra note 14, at 50.

21. In the well-turned phrasing of a recent California Supreme Court opinion, it was stated:

[I]n our complex and interdependent society, human relations are ever being further fit into a framework of legal rights and responsibilities, and, in this process, the role of the lawyer has become increasingly crucial. As more individuals come to depend upon him, his responsibility must broaden and deepen. Neel v. Magana, Olney, Levy, Cathcart \& Gelfand, 6 Cal. 3d 176, 194, 491 P.2d 421, 432-33, 98 Cal. Rptr. 837, 848-49 (1971).

In Neel the court brought the California rule covering the running of the statute of limitations for lawyers' malpractice in line with the rule applied in cases of malpractice by other professionals. 
nized duties owed to new constituencies. As the following discussion demonstrates, just as the businessinan can no longer escape liability for his defective goods once they are resold by his immediate vendee, lawyers are similarly encountering an increasing willingness on the part of courts to impose liability for slipshod legal work in favor of those persons who could have foreseeably been expected to be affected directly by or led to rely on the lawyer's toil. In other words, the requirement of privity in malpractice cases belongs on a list of endangered species.

The saga of the corporate lawyer's emerging responsibilities is far from being simply the story of a developing framework of substantive liability, however. There is inherent in the idea of the lawyer's being favored with a inonopoly license to practice law the premise that his perfornnance as a professional will be subjected to self-regulation by the lawyer himself and to more formal regulation by the profession as a whole. As we start this survey of the contours of the lawyer's role in preparing legal opinions, it should be kept in mind that there is a good deal inore to our study than mapping out the limits of a lawyer's substantive exposure to legal sanctions. For one thing, the law of professional malpractice is in flux, and this situation makes the use of yesterday's guidelines to chart today's actions dangerous business. Further, the concept of litigation as a distasteful way to settle disputes is fundamental to our legal system. ${ }^{22}$ How much more unpalatable is the use of litigation to obtain guidelines for professional development?

\section{DeVelopments IN Malpractice LaW}

\section{The Standard of Care}

Legal malpractice consists of the failure of an attorney "to use such skill, prudence, and diligence as lawyers of ordinary skill and capacity commonly possess and exercise in the performance of the tasks which they undertake." ${ }^{23}$ When such failure proximately

22. Indeed, the American Bar Association's pamphlet setting forth the Code of Professional Responsibility pointedly includes the following quotation from Abraham Lincoln:

Discourage litigation. Persuade your neighbors to compromise whenever you can. Point out to them how the nominal winner is often the real loser-in fees, expenses and waste of time. As a peacemaker, the lawyer has a superior opportunity of being a good man. CODE OF Professional ResPONSIBILITY, supra note 16, at 48.

23. Lucas v. Hamm, 56 Cal. $2 d$ 583, 591, 364 P.2d 685, 689, 15 Cal. Rptr. 821, 825 (1961). See generally Leavitt, The Attorney as Defendant, 13 HASTINGS L.J. 1, 23-32 (1961); Wade, The Attorney's Liability for Negligence, 12 VAND. L. Rev. 755, 762-65 (1959); Note, Attorney Malpractice, 63 Colum. L. Rev. 1292, 1294-1302 (1963). 
causes damages, it gives rise to a cause of action in tort. ${ }^{24}$ Moreover, since in the usual case the attorney has undertaken to perform his duties pursuant to a contract with his client, his failure to exercise the requisite skill and care is also a breach of an express or implied term of that contract. ${ }^{25}$ Thus, an instance of legal malpractice will generally, give rise to both a cause of action in tort and a breach of contract claim. ${ }^{26}$

Obviously, not every miscue by an attorney will give rise to malpractice liability. As the California Supreme Court pointed out in Lucas v. Hamm, ${ }^{27}$

[t] he attorney is not liable for every mistake he may make in his practice; he is not, in the absence of an express agreennent, an insurer of the soundness of his opinions or of the validity of an instrument he is engaged to draft; and he is not liable for being in error as to a question of law on which reasonable doubt may be entertained by well-informed lawyers . . . . These principles are equally applicable whether the plaintiff's claim is based on tort or breach of contract. 28

The court's smcerity in its proclamation that an attorney is not "an insurer of his opinions or of the validity of an instrument he is engaged to draft" is established by its refusal to allow recovery from the defendant attorney for misinterpreting the Rule Against Perpetuities, notwithstanding that the particular blunder committed could have been avoided had the defendant consulted decisional authority interpreting the Rule that was on the books at the time the defective instrument was drafted. ${ }^{29}$ Noting that the Rule had been referred to as "a dangerous instrumentality in the hands of most nembers of the bar," ${ }^{30}$ the court felt that the level of skill exercised by the defendant was in lime with that generally used by lawyers.

To be distinguished from instances involving negligent inalpractice by attorneys are those cases where the attorney's wrongful con-

24. Cf. Averill, Attorney's Liability to Third Parties for Negligent Malpractice, 2 LAND \& WATER L. ReV. 379 (1967).

25. E.g., Savings Bank v. Ward, 100 U.S. 195, 198 (1880); Wilcox v. Executors of Plummer, 29 U.S. (4 Pet.) 172 (1830).

26. E.g., Lucas v. Hamm, 56 Cal. 2d 583, 589 n.2, 364 P.2d 685, 688 n.2, 15 Cal. Rptr. 821, 824 n.2 (1961); Wade, supra note 23; Note, supra note 23, at 1292-94.

27. 56 Cal. 2d 583, 364 P.2d 685, 15 Cal. Rptr. 821 (1961).

28. Id. at 591-92, $364 \mathrm{P} .2 \mathrm{~d}$ at 689, 15 Cal. Rptr. at 825 (citations omitted).

29. See Note, supra note 23 , at 1297.

30. Lucas v. Hamm, 56 Cal. 2d 583, 592, 364 P.2d 685, 690, 15 Cal. Rptr. 821, 826 (1961), quoting Leach, Perpetuities Legislation, Massachusetts Style, 67 HARV. L. REV. 1349 (1954). 
duct involves fraud. A professional may be held liable for fraud based on either an intentional misrepresentation or a representation made where there was no basis for a belief in its accuracy. New York's highest court has stated the rule as follows:

A representation certified as true to the knowledge of the accountants when knowledge there is none, a reckless misstatement, or an opinion based on grounds so flimsy as to lead to the conclusion there was no genuine belief in its truth, are all sufficient upon which to base liability [for fraud]. A refusal to see the obvious, a failure to investigate the doubtful, if sufficiently gross, may furnish evidence leading to an inference of fraud so as to impose liability for losses suffered by those who rely on the balance sheet. In other words, heedlessness and reckless disregard of consequences may take the place of deliberate intention. ${ }^{31}$

\section{The Limits of Liability}

The significance of the distinction between negligent malpractice and professional misconduct amounting to fraud is found in the degree of exposure to liability resulting from the wrongdoing. In the case of fraudulent misrepresentation, a misrepresenter may be held liable to all persons whoin he should reasonably have foreseen would be imjured by his misrepresentation. ${ }^{32}$ On the other hand, the limits of an attorney's exposure for negligent malpractice are not so easy to define. Venerable authority demonstrating two conflicting views is the Supreme Court's 1880 decision in Savings Bank v. Ward. $^{33}$ In that case, the defendant attorney had conducted a title search and had given his client a certificate stating the legal opinion that the land was held by the chient in fee simple. Relying on the certificate, the plaintiff bank made a loan to the client secured

31. State Street Trust Co. v. Ernst, 278 N.Y. 104, 112, 15 N.E.2d 416, 419 (1938). See also Rusch Factors, Inc. v. Levin, 284 F. Supp. 85, 90 (D.R.I. 1968) ("[t]he same broad perimeter [applicable to intentional misrepresentation] prevails if the misrepresenter's conduct is heedless enough to permit an inference of fraud"); Ultramares Corp. v. Touche, 255 N.Y. 170, 189, 174 N.E. 441, 448 (1931) (speaking of the liability of accountants for their audit, Judge Cardozo observed that "if their audit has been so negligent as to justify a finding that they had no genuine belief in its adequacy . . . this . . . is fraud").

32. E.g., Savings Bank v. Ward, 100 U.S. 195, 205 (1880); Rusch Factors, Inc. v. Levin, 284 F. Supp. 85, 90 (D.R.I. 1968). The court in Rusch Factors gave several reasons in support of a broad right of recovery in cases of fraudulent misrepresentation:

First, liability should extend at least as far in fraud, an intentional tort, as it does in negligence cases resulting in personal injury or property damage. Second, the risk of loss for intentional wrongdoing should invariably be placed on the wrongdoer who caused the harm, rather than on the innocent victim of the harm. Finally, a broad rule of liability may deter future misconduct. Id. (citation omitted).

33. 100 U.S. 195 (1880). 
by the realty. When the client defaulted and the deed proved worthless, the bank sued for malpractice.

Reasoning from cases such as Winterbottom $v$. Wright, ${ }^{34}$ a sixjustice majority ruled that lack of privity with the defendant attorney barred the plaimtiff from recovery. The contrary view was succinctly stated by Chief Justice Waite on behalf of the minority:

I think if a lawyer, employed to examime and certify to the recorded title of real property, gives his client a certificate which he knows or ought to know is to be used by the client in some business transaction with another person as evidence of the facts certified to, he is liable to sucl other person relying on his certificate for any loss resulting from his failure to find on record a conveyance affecting the title, which, by the use of ordinary professional care and skill, he might have found. That, it seeins to me, is this case..$^{35}$

Thus, the Ward case represents a confrontation between the view that privity is a sine qua non for negligent malpractice recovery and the position that, where reliance is or should be foreseen, recovery may be had by one member of a foreseeable class who relies on a lawyer's judgment. ${ }^{36}$ Although Ward is obviously of importance to an understanding of the bounds of a lawyer's responsibility for his legal opinions, it is by no means the only pertinent authority, because, as we shall see, the boundaries of lawyers' opinion letter exposure are to a great extent shaped by developments in professional malpractice law generally.

Two important decisions by the New York Court of Appeals, Glanzer v. Shepherd ${ }^{37}$ and Ultramares Corp. v. Touche ${ }^{38}$ add further defimition to the general scope of a professional's liability for negligence. Glanzer involved a suit by a third party against a public weigher who had negligently overweighed a load of beans, causing the plaintiff to pay for more beans that were received. The defendants client had requested that the defendant furnish the plaintiff with a return of the weight, so reliance by the plaintiff on the defendant's work was clearly foreseeable. On these facts, Judge Cardozo had no difficulty allowing recovery by the plaintiff. Lack

34. 152 Eng. Rep. 402 (1842).

35. Savings Bank v. Ward, 100 U.S. 195, 207 (1880).

36. While the identity of the plaintiff in Ward was not foreseen by defendant attomey, reliance on the certificate of title was clearly a foreseeable act since such certificates are commonly used as a basis for making loans. Sce Annot., Attorney's Liability, to One Other than His Immediate Client, For Consequences of Negligence in Carrying Out Legal Duties, 45 A.L.R.3d 1181, 1200 (1972).

37. 233 N.Y. 236,135 N.E. 275 (1922).

38. 255 N.Y. 170,174 N.E. 441 (1931). 
of privity was no barrier, the court held, since "[g]iven the contract and the relation the duty is imposed by law."39

In contrast with Glanzer, Ultramares involved an action brought against an accounting firm by a creditor whose reliance on financial statements was found to be unforeseen in fact, though reliance by soine creditor was or should have been foreseen since the accountants knew that their client's operation required large amounts of credit and that the certified financial statements would be circulated to creditors. The defendant in Ultramares was alleged to have certified wrongfully that a balance sheet accurately reflected a one million dollar net worth when the audited company was insolvent. The plaintiff alleged that in reliance on the bogus balance sheet he had loaned money to the insolvent company. Since the defendant's negligence was clear, the only question for the court was whether the dedefendant had breached a duty owed to the plaintiff. Again writing for the majority, Judge Cardozo this time refused to find the requisite duty. Glanzer was held to be inapposite because there the service rendered was primarily for the information of the identified third party and only incidentally for the formal promisee. The defendant in Ultramares, on the other hand, was said to have certified the financials primarily for the benefit of its client and only incidentally or collaterally for the use of those individuals to whom the statements might be exhibited. ${ }^{40}$

The motivating force behind the court's decision to deny liability appears to spring from the same sentiment that underlies modern holdings which refuse to sanction use of the class action where to do so would result in massive hability. Just as such recent cases have decried the possibility of "horrendous, possibly annihilating punishment," $"$ Ultramares discloses an expression of the fear that to im-

39. 233 N.Y. at 239,135 N.E. at 276 (citation omitted).

40. 255 N.Y. at $182-83,174$ N.E. at $445-46$.

41. E.g., Kriger v. European Health Spa, Inc., 56 F.R.D. 104 (E.D. Wis. 1972); Rogers v. Coburn Fin. Corp., 54 F.R.D. 417 (N.D. Ga. 1972); Ratner v. Chemical Bank N.Y. Trust Co., 54 F.R.D. 412 (S.D.N.Y. 1972). These cases were brought under the Truth in Lending Act, 15 U.S.C. $\$ \S 1601-81$ (1970). Section 130 (a), id. $\S 1640$ (a), provides for a minimum recovery of $\$ 100$ by any person aggrieved by a violation of the exceedingly technical act. For another example of a court bending under the influence of public policy considerations and refusing to expand the parameters of liability to the fullest extent imaginable, see Hall v. Coburn Corp., 26 N.Y.2d 396, 311 N.Y.S.2d 281, 259 N.E.2d 720 (1970). The defendant in Hall had used less than 8 point type in its sales contracts in violation of section 402 of the New York Retail Installment Sales Act, N.Y. Pers. Prop. LAw c. $41, \S 402$ (McKinney 1962). In cases of violation, the Installment Sales Act provided for recovery of the finance charges imposed, and plaintiff sought recovery for herself and a class of all persons having contracts 
pose liability in favor of the plaintiff creditor would lead to a rule exposing professionals to liability for negligence "in an indeterminate amount for an indeterminate time to an indeterminate class." ${ }^{22}$ This essential policy commitment to protection of professionals from widespread liability for careless error did not, in the court's mind at least, conflict with the policy of giving recognition to the reasonable expectations of a party not in privity, since the court doubted whether "the average businessinan receiving a certificate without paying for it, and receiving it merely as one of a multitude of possible investors," would expect to recover froin the certifying accountant for an "honest blunder."43

At a time when Dean Prosser's citadel of privity has been pretty much reduced to rubble and when courts are increasingly unwilling to bar recovery in products liability cases on the ground that the damage done was economic harm rather than personal injury, ${ }^{44}$ there is strong reason to doubt whether courts will be content either to

using similar type size. The court refused to allow recovery on behalf of the class, saying that "[t]he public value" of class action relief was "open to substantial doubt" since the suit did not address "the real evil of retail credit buying," which was identified as "the heavy cost of credit to consumers." Hall v. Coburn Corp., 26 N.Y.2d at 403,311 N.Y.S.2d at 285,259 N.E.2d at 723. Though the Hall case has been criticized as "outrageous procedural law," the result achieved is hardly shocking in light of such decisions as Ratner, Rogers and Kriger. See Dole, Private Enforcement of Consumer Credit Legislation, 26 Bus. LAw. 915, 923 (1971).

In a similar vein one may wonder whether it can be said that recovery by a person iujured by management malfeasance, in a suit against accountants who fail to uncover the malfeasance, really addresses itself to the aim of preventing or minimizing instances of mismanagement. It would seem germane for a court called upon to rule in an Ultramares-type setting to consider whether an extra measure of diligence could be wrung out of the defendant professional by a liability decree, and if so, whether this benefit might not be outweighed by inhibitions on the profession's ability to function in a climate where the threat of devastating punislıment for honest blunders would attend everyday actions.

42. 255 N.Y. at 179, 174 N.E. at 444 . One major difference between the class action cases such as Ratner, Rogers, Kriger and Hall and the factual setting of Ultramares deserves mention. In the class actions, the damages that would have been imposed pursuant to applicable statutory provisions (such as the $\$ 100$ minimum under the Truth in Lending Act), would not necessarily lave borne any relation to actual economic harm. This would not be the case in a malpractice suit.

43. Id. at 189,174 N.E. at 448.

44. The leading case allowing recovery for economic harm under a strict linbility theory is Santor v. A \& M Karagheusian, Inc., 44 N.J. 52, 207 A.2d 305 (1965). For a discussion of the issues involved and additional cases on point, see Annot., Privity of Contract as Essential in Actions Against Remote Manufacturcr or Distributor for Defects in Goods Not Causing Injury to Person or to Other Property, 16 A.L.R.3d 683 (1967). 
follow Ultramares on its facts or to honor Judge Cardozo's dicta that the right to recovery for negligent malpractice "is one that is bounded by the contract." 45 Presaging a break with the traditional pro-privity view is the tentative draft of section 552 of the Restatement (Second) of Torts. ${ }^{46}$ Under the terms of the section, liability for negligent malpractice may be imposed on a defendant in favor of a reliant party not in privity whether or not the defendant knew of the injured party's identity at the time of the negligent act; ${ }^{47}$ it is sufficient that the plaintiff be a person or a member of a class of persons for whose benefit or guidance the defendant intended to supply informa-

45. 255 N.Y. at 189,174 N.E. at 448 . Despite this language it is, of course, still possible to use Glanzer to support a judgment of liability in the face of a lack of privity where the plaintiff's reliance was actually foreseen at the time the malpractice was committed. E.g., Rusch Factors, Inc. v. Levin, 284 F. Supp. 85 (D.R.I. 1968); Ryan v. Kanne, 170 N.W.2d 395 (Iowa 1969). Nevertheless, some courts have cliosen to read Ultramares as limiting recovery for negligent inalpractice to those bound by the contract. E.g., Stephens Indus. Inc. v. Haskins \& Sells, 438 F.2d 357, 359 (10th Cir. 1971); State Street Trust Co. v. Ernst, 278 N.Y. 104, 15 N.E.2d 416 (1938); Duro Sportswear, Inc. v. Cogen, 131 N.Y.S.2d 20 (Sup. Ct. 1954). In both State Street Trust Co. and Duro the identity of the reliant party was known beforehand by defendant accountant. The Duro case is criticized in Bradley, Liability to Third Persons for Negligent Audit, 1966 J. Bus. LAW 190, 193.

46. Restatement (Second) of Torts $\$ 522$ (Tent. Draft No. 12 1966). The section reads as follows:

(1) One who, in the course of his business, profession, or einployment ... supplies false information for the guidance of others in their business transactions, is subject to liability for pecuniary loss caused to thein by their justifiable reliance upon such information, if lie fails to exercise reasonable care or competence in obtaining or communicating the information.

(2) Except as stated in subsection (3), the liability stated in subsection (1) is limited to loss suffered

(a) by the person or one of the persons for whose benefit and guidance he intends to supply the information, or knows that the recipient intends to supply it; and

(b) through reliance upon it in a transaction which he intends the information to influence, or knows that the recipient so intends, or in a substantially similar transaction.

(3) The liability of one who is under a public duty to give the information extends to loss suffered by any of the class of persons for whose benefit the duty is created, in any of the transactions in which it is intended to protect them.

47. In other words, it is not required that the person wlio is to becone the plaintiff be identified or known to the defendant as an individual when the information is supplied. It is enough that the inaker of the representation intends it to reach and influence either a particular person or persons, known to him, or a group or class of persons, distinct from the much larger class who might reasonably be expected sooner or later to liave access to the information, and foreseeably to take some action in reliance upon it. It is enough, likewise, that the maker of the representation knows that the recipient intends to transmit the information to a similar person, persons, or group. It is sufficient, in other words, that the maker knows that the information is intended for repetition to a certain group or class of persons, and that the plaintiff proves to be one of them, even though the maker never liad heard of him when the information was given. Id., comment $h$, at 23 . 
tion, or to whom the defendant knew the information would be supplied. ${ }^{48}$

In repudiating Ultramares, the Restatement essentially elevates to majority status the dissent of Chief Justice Waite in Ward nearly a century ago. ${ }^{49}$ The only difference between the two views is that the Restatement frames the scope of the duty owed in terms of the actual perception of potentially reliant parties by the actor. On the other hand, the Ward dissent's formulation goes further and reaches "should have known" cases. The dissent would allow establishment of the requisite duty owed by reason of inferred knowledge of intended reliance based on custoin and usage-such as reliance on opinions as to the state of title by lenders. Whether this distinction has any real significance is open to serious question, since in either case the expectation of the reliant third party in a quality work product would be the same, and it is mainly in terms of giving effect to the reasonable expectations of the reliant third party that any sense can be made of extending the professional's malpractice exposure beyond the bounds of privity. ${ }^{50}$

Section 552's potential for being read to signal the demise of Ultramares has not been ignored by the courts. In Rusch Factors,

48. A hypothetical situation based on one of a series used by the section's draftsmen illustrates their intention to part with Ultramares and its progeny. $A$ is negotiating with a Bank for a credit of $\$ 50,000$. The Bank requires an audit by certified public accountants. A employs B \& Company, a firm of accountants, to make the audit, telling them he is going to negotiate a bank loan. A does not get his loan from the first bank but does negotiate a loan with another bank, which relies upon B \& Company's certified statements. The audit carelessly overstates the financial resources of $\mathrm{A}$, and in consequence the second bank suffers pecuniary loss. B \& Company is subject to liability to the second bank. Id., illustration 4, at 24 .

49. See note 35 supra and accompanying text.

50. This analysis is not meant to give the Restatement a broader reading than it deserves, however. Another illustration used by the draftsmeu demonstrates their intention that the scope of malpractice exposure of accountants should not extend to every instance where a plaintiff could allege reliauce on certified financials. RESTATEMENT (SECOND) OF TORTS, supra note $46, \S 552$, illustration 7 , at 25 . The only point made here is that in the case of an opinion given for a well-recognized purpose that customarily involves reliance by third parties, such as a certificate of title, there does not seem to be anything extreme in upholding a right to recovery on behalf of an injured reliant party. As the discussion below of different types of legal opinions indicates, there is much room for this middle ground between the Restatement's individual, who is a reliant member of an actually foreseen class, and Judge Cardozo's member of the "indeterminate class" of all persons who might foreseeably rely on an opinion.

It should be noted that there are other justifications for allowing recovery from professionals in addition to the interest in insuring that a reliant third party recoups his losses. See note 52 infra and text accompanying note 58 infra. 
Inc. v. Levin ${ }^{51}$ the provision was cited favorably by the district court en route to its holding that a finance company had stated a good cause of action against an accountant who was alleged to have negligently certified financial statements rehied on by the plaintiff. While the facts in question revealed that rehance by the plaintiff had been clearly foreseen by the defendant accountant, making the situation more analogous to Glanzer than Ultramares, the court nevertheless took the occasion to denounce Ultramares in no uncertain terms. ${ }^{52}$ The court further ruled that the plaintiff had stated a good cause of action in fraud, noting that privity was no barrier in such cases and that proof of gross negligence could suffice for recovery. ${ }^{53}$

The reasoning of the court in Rusch Factors with respect to the demise of privity as a prerequisite for recovery found favor with Iowa's Supreme Court in Ryan v. Kanne. ${ }^{54}$ Like the court in Rusch Factors, the Iowa court castigated Ultramares as "an unwarranted inroad upon the primciple that the risk reasonably to be perceived defines the duty to be obeyed."55 Needless to say, the court in Ryan, like the court in Rusch Factors, had no difficulty permitting recovery in favor of a party who was actually foreseen by the defendant accountant at the time the financial statements in question were prepared.

Adding to the significance of the sentiments expressed in section 552, Rusch Factors, and Ryan is the apparent willingness of California's Supreme Court to depart from precedent extending all the way back to the decision of the United States Supreme Court in Ward. Thus in Biakanja v. Irving, ${ }^{58}$ the court rejected prior precedent $^{57}$ and allowed a beneficiary of an invalid will to recover from the individual who negligently failed to have it attested properly. The following analysis was offered to assist courts called on in the future

51. 284 F. Supp. 85 (D.R.I. 1968).

52. The wisdom of the decision in Ultramares had been doubted . . . and this Court shares the doubt. Why should an innocent reliant party be forced to carry the weighty burden of an accountant's professional malpractice? Isn't the risk of loss more easily distributed and fairly spread by imposing it on the accounting profession, which can pass the cost of insuring against the risk onto its customers, who can in turn pass the cost onto the entire consuming public? Finally, wouldn't a rule of foreseeability elevate the cautionary techniques of the accounting profession? For these reasons it appears to this Court that the decision in Ultramares constitutes an unwarranted inroad upon the principle that "[t]he risk reasonably to be perceived defines the duty to be obeyed." Id. at 90-91.

53. Id. at 90 .

54. 170 N.W.2d 395 (Iowa 1969).

55. Id. at 401.

56. $49 \mathrm{Cal} .2 \mathrm{~d} 647,320$ P.2d 16 (1958).

57. Buckley v. Gray, 110 Cal. 339, 42 P. 900 (1895). 
to determine the rights of third parties allegedly injured by negligent malpractice:

The determination whether in a specific case the defendant will be held liable to a third person not in privity is a matter of policy and involves the balancing of various factors, among which are the extent to which the transaction was intended to affect the plaintiff, the foreseeability of harm to him, the degree of certainty that the plaintiff suffered injury, the closeness of the connection between the defendant's conduct and the injury suffered, the moral blame attached to the defendant's conduct, and the policy of preventing future harm. ${ }^{58}$

The California court's rejection of a set test to measure exposure in malpractice cases leaves needed room for recognition of the widely varying circuinstances in which professionals act and render their opinions. While this flexibility is of limited significance in the case of audit certificates in view of their essentially homogeneous nature, legal opinions are issued in widely varying contexts requiring individual analysis of the type called for in Biakanja..$^{58}$

In concluding this brief outline of professional malpractice, one might well note again that the times have changed. Courts are a good deal more venturesome in this area than they once were. The core of the Supreine Court's pro-privity reasoning in Ward was expressed in its claim that "[t]he only safe rule is to confine the right to recover to those who enter into the contract; if we go one step beyond that, there is no reason why we should not go fifty." In sharp contrast with this stance is the considerably more aggressive attitude adopted by the California Supreme Court in a recent decision that brings the statute of limitations period for malpractice by lawyers in line with that for malpractice by other professionals. In that case the court einphasized that "[t]he legal calling can ill afford the preservation of a privileged protection against responsibility." While the requirement of privity in malpractice cases is still adhered to in many states, California is not one of them, and given the California Supreme Court's impressive credentials as a trend-setter, ${ }^{62}$

58. Biakanja v. Irving, 49 Cal. $2 \mathrm{~d} 647,650,320$ P.2d 16, 19 (1958).

59. For discussion of some differing contexts in which legal opinions are issued, see pp. 387-96 infra.

60. 100 U.S. at 203 (1880).

61. Neel v. Magana, Olney, Levy, Cathcart \& Gelfand, 6 Cal. 3d 176, 194, 491 P.2d 421, 433, 98 Cal. Rptr. 837, 849 (1971).

62. Consider, for example, the very warm reception given the California Supreme Court's landmark collateral estoppel decision of Bernhard v. Bank of Am. Nat'1 Trust \& Sav. Ass'n, 19 Cal. 2d 807, 122 P.2d 892 (1942). See, e.g., Blonder-Tongue Labs., Inc. v. University of Ill. Foundation, 402 U.S. 313, 323-24, 326-27, 349 (1971); Goolsby v. Derby, 189 N.W.2d 909 (Iowa 1971); Pennington v. Snow, 471 P.2d 370 (Alaska 1970); Bahler v. Fletcher, 257 Ore. 1, 474 P.2d 
the handful of courts that have already joined California in discarding the need for privity may expect a good deal of company as time goes on. ${ }^{63}$ This likely development has a number of implications regarding the exposure of lawyers for negligence in rendering opinion letters, and those implications are discussed in the next section.

\section{Implications of Different Opinion LetTer Settings}

In these days of the ubiquitous opinion poll, it is not surprising that one pollster claims to have made a survey of lawyers' perceptions of their exposure to liability for the quality of their legal opinions.

329 (1970); Currie, Civil Procedure: The Tempest Brews, 53 CarIf. L. Rev. 25 (1965); Currie, Mutuality of Collateral Estoppel: Limits of the Bernhard Doctrine, 9 STAN. L. Rev. 281 (1957). There is a clear analogy that may be drawn between the California court's rejection of the mutuality doctrine in collateral estoppel cases and its refusal to adhere to the strict need for privity espoused by Ward. The mutuality rule has been attacked "as destitute of any semblance of reason, and as 'a maxim which oue would suppose to have found its way from the gaming-table to the bench' ...." Zdanok v. Glidden Co., 327 F.2d 944, 954 (2d Cir.), cert. denied, 377 U.S. 934 (1964), quoting 3 J. BENTHAM, RATTONAlE OF JUdiclat Evidence 579 (1827). There appears to be little to choose from between the lack of logic criticized by Benthain and the hollow argument advanced by the Supreme Court in Ward that the "only safe rule" is to bar recovery by those not in privity, because "if we go one step beyond that, there is no reason why we should not go fifty." 100 U.S. at 203.

63. In addition to Rusch Factors and Ryan v. Kanne, several cases evidence a willingness to abandon Ward where the alleged wrongdoer actually knew of the third party's intended reliance or appreciated that the intent of the transaction was to benefit the third party. See Robinson v. Colebrook Guar. Sav. Bank, 109 N.H. 382, 254 A.2d 837 (1969) (holding that third party stated a good cause of action on allegation of negligence against bank where phrase "payable on death to $X$ " used for savings account was legally insufficient); Howarth v. Pfeiffer, 443 P.2d 39 (Alaska 1968) (plaintiff was allowed to recover from defendant insurer who told plaintiff that property was insured by $X$, causing plaintiff to cancel his insurance); Shatterproof Glass Corp. v. James, 466 S.W.2d 873 (Tex. App. 1971) (accountants held liable for preparation of financial statements they knew would be relied upon by plaintiff in extending loan to their client). But see Stephens Indus., Inc. v. Haskins \& Sells, 438 F.2d 357 (10th Cir. 1971) (refusing to find that Colorado courts would allow recovery from negligent accountants by third party).

The movement toward the abandonment of privity recently received a significant nudge in the form of an American Law Reports annotation arguing that "the strict privity doctrine, with its potential for unrecompensable injury to innocent parties ... [does not present] a workable solution to the question of an attorney's liability to third parties." Annot., supra note 36, at 1185 (1972). The Annotation advocates an eclectic approach similar to that advanced by the California Supreme Court in Biakanja. It is also worthy of note that England's highest court appears to have adopted the view that professionals may be held liable for negligence without regard to privity. See Hedley Byrne \& Co. v. Heller \& Partners, Ltd., [1964] A.C. 465 (1963). The Hedley Byrne case essentially adopts the "knew or should have known" approach advocated in the Ward dissent. See Accountants Liability to Third Parties-The Hedley Byrne Decision, $120 \mathrm{~J}$. ACCOUNTANCY, Oct., 1965, at 66-67. 
The survey, undefined as to scope and bearing no claim of statistical accuracy, is said to have yielded the conclusion that lawyers do not expect to be held answerable for their written opinions. ${ }^{84}$ While the cases discussed in the preceding section seem to indicate that a change in such an outlook may be inerited, it is recognized that cases such as Rusch Factors and Ryan v. Kanne deal only with accountants, and thus there is rooin for the argument that their teachings have no applications to lawyers in light of the different roles played by the two professions in our society. Proponents of the view that the two professions are worlds apart in terms of public accountability inay draw support from dicta in the SEC's decision in American Finance $\mathrm{Co}^{65}$ In that ruling the SEC determined that an accountant who also served as a lawyer for a registrant was not "independent" under the SEC's Accounting Rules. ${ }^{68}$ The pertinent language in the Commission's decision reads as follows:

Though owing a public responsibility, an attorney in acting as the client's advisor, defender, advocate and confidant enters into a personal relationship in which his principal concern is with the interests and rights of his client. The requireinent of the Act of certification by an independent accountant, on the other hand, is intended to secure for the benefit of public investors the detached objectivity of a disinterested person. ${ }^{\circ 7}$

64. Corso, Opinions of Counsel: Responsibilities and Liabilities, 17 CLEV.-MAR. L. REv. 375 (1968).

65. 40 S.E.C. 1043 (1962).

66. The Commission's rule as to the independence of accountants is set forth in 17 C.F.R. $\$ 210.2-01$ (b) (1972). See also SEC Accounting Series Release No. 126 (July 5, 1972) (setting forth guidelines and examples of situations involving independence of accountants).

67. American Fin. Co., 40 S.E.C. 1043, 1049 (1962). To the same effect are the following remarks made by Milton V. Freeman at the American Bar Association's National Institute on the BarChris case:

Now, you ask why is it, if there is a development of the law in the direction of liability on accountants, that there should not be liability upon lawyers equally?

The answer is, I think, in the nature of the representation that is made by each.

I have here the language of the American Institute of Accountants which says: "I am objective and impartial. I am as mindful of the interests of strangers who may rely on my opinion as on iny clients' interests."

I know no lawyer would ever say that. A lawyer says, "I am a partisan. I have been retained by my clients. I owe him my full loyalty and responsibility. I want everybody to know that those are the rules of my profession."

The accountant makes an entirely different kind of representation and there are indeed signs that the law is moving in the direction of holding accountants liable to somebody other than his client.

The law, so far, is very clear. The lawyers' responsibility is exclusively to their own client. Proceedings, ABA Nat'l Institute, The BarChris Case: Prospectus Liability, 24 Bus. LAw. 523, 639 (1969).

See also Karmel, supra note 4, at 1162-64. 
The principal shortcoming of any abstract argument designed to distinguish the public responsibilities of lawyers from those of accountants is, of course, that stereotypes are useless in deciding concrete cases-accountants do not always function as relentless bloodhounds and lawyers do not in every circumstance serve as kindly father-confessors. An argument built around emphasis on a lawyer's "traditional role" fails to account for cases where there is virtually no distinction between the action taken by a lawyer and the service rendered by an accountant. And it is in the rendition of formal opinions that the services perforined by the two professions shade together and become indistinguishable. In this area, to hold accountants responsible for their opinions and, at the same time, to permit lawyers to escape liability would indeed vest the legal calling with a "privileged protection against responsibility."

\section{Municipal Bond Opinions}

While the essential similarity of the lawyer's opinion and the accountant's audit certificate has not escaped the notice of the courts or the commentators, ${ }^{69}$ this likeness does not mean that the two types of professional opinions must perforce be taken to be identical im nature and consequence. The inappropriateness of trying to compare a certain type of legal opinion to the auditor's certificate witlout regard to the setting in which the legal opinion is rendered is strikingly illustrated by a false step taken by Judge Cardozo in his Ultramares opinion. In the course of his discussion of the policy reasons for limiting the exposure of accountants to the parameters of privity, Judge Cardozo said that the expansion of liability for negligence to accountants would likewise encompass the conduct of "many callings other than an auditor's," mcluding "[1] awyers who certify their opinion as to the validity of inunicipal or corporate bonds with knowledge that the opinion will be brought to the notice of the public."70 Given the validity of the court's doubt in Ultramares that the "average businessman" who had invested in a company would expect to recover from a company's accountants for their negligence in auditing the company's books, ${ }^{71}$ the accountant/

68. See text accompanying note 61 supra.

69. See SEC v. Frank, 388 F.2d 486, 489 (2d Cir. 1968); United States v. Danser, 26 F.R.D. 580, 587 (D. Mass. 1959), aff'd, 281 F.2d 492 (1st Cir. 1960); Ultramares Corp. v. Touche, 255 N.Y. 170, 188, 174 N.E. 441, 448 (1931); Note, Public Accountants and Attorneys: Negligence and the Third Party, 47 Notre DaME LAw. 588, 607 (1972).

70. 255 N.Y. at 188, 174 N.E. at 448 (1931).

71. Id. at 189,174 N.E. at 448. 
bond counsel analogy is infirm since an investor purchasing a bond for which a legal opinion had been issued has a very legitimate basis for the opposite expectation. As one practitioner has pointed out,

[t]hose of you who have ever fooled around in the field of municipal bonds would not be so surprised at the notion of a lawyer's opinion running to the public. I will never forget my utter horror when I found that an opinion given on a security by bond counsel not only is rehed upon by the public and the purchasers, but is stapled to the security and later printed on the back of the security, as indeed it still is today. . . . The bond counsel firm is chosen because its reputation in the field is such that purchasers will buy the security relying on the opinion of the firm and that opinion, thereafter, accompanies the security through its life. ${ }^{72}$

Just as Judge Cardozo's municipal bond opinion/auditor's certificate analogy is questionable from the standpoint of third parties' reasonable expectations, so also is there reason to question whether the same policy considerations that attend the issuance of audit certificates likewise apply in the case of municipal bond opinions. In the audit certificate situation, the Ultramares court apparently determined that the public's interest in the effective functioning of business affairs was best served by allowing accountants to act as independent historians and report on busmess performance free from the threat of broad liability for honest errors. One may wonder whether a similar interest is served by allowing a law firm to make the representations and foster the reliance that exists in the bond area free from the threat of hability to those persons who justifiably rely on the firm's opinion. Such an exemption from liability is particularly questionable where the firm allows its good name to be used to enhance the value of the security to which the opinion is attached.

Because of the arguably different expectations on the part of investors and in light of seemingly different pohicy considerations that arise with respect to bond opinions and audit certificates, it is certainly possible that a court committed to Ultramares on the issue of auditors' liability might choose not to shield similarly bond counsel from liability for a negligently rendered opinion. This same type of reasoning may come into play in the context of opinions issued in connection with public offerings.

72. Panel Discussion, supra note 20, at 961 (remarks of Frederic L. Ballard). Accord, Transcrupt, supra note 14, at 169 (remarks of A.A. Sommer); cf. id. at 73-74 (discussing the implications of disclosure that a law firm serves as general counsel). 


\section{Public Offering Opinions}

A similar situation involving the use of counsel's name in an attempt to enhance the value of a security arises in the public offering area. Of the two sorts of opinions rendered in connection with a public offering, the first type sets forth a lawyer's judgment on specific legal matters that are of inportance to the offering. These matters may include due incorporation of the issuer, proper issuance of the securities, and tax consequences. Opinions of this sort are disclosed in the registration statement and counsel recognize that they are prepared and disclosed "for the benefit . . . of all purchasers of the stock."73 In addition to the possibility of common law liability for an error in the rendition of this first type of opinion, there is the threat that counsel may be held liable as an expert under section 11 of the Securities Act of 1933 (1933 Act) $^{74}$ to purcliasers of the issue.

In brief, section 11 gives a right of civil recovery to persons who purchase securities issued in conjunction with a materially misleadimg registration statement ${ }^{75}$ filed pursuant to section 5 of the 1933 Act. ${ }^{78}$ Lack of privity is no barrier to suit, ${ }^{77}$ and proof of reliance on the misrepresentation is not strictly required. ${ }^{78}$. Thus, the effect of section 11's intricate civil recovery scheme is to undercut Ultramares with respect to accountants and other persons "whose profession gives authority" to their work and who consent to being

73. Officers' and Directors' Institute, supra note 18, at 135 (remarks of Robert A. McDowell).

74. 15 U.S.C. $\& 77 \mathrm{k}(1970)$.

75. For standing to sue to exist, the shares held by the plaintiff must have been issued pursuant to the registration statement in question and not some other registration statement. Colonial Realty Corp. v. Brunswick Corp., 257 F. Supp. 875 (S.D.N.Y. 1966) (defendant's motion for summary judgment granted because plaintiff had not purchased shares issued pursuant to the allegedly misleading registration statement).

76. Securities Act of $1933 \S 5,15$ U.S.C. $\$ 77 \mathrm{e}(\mathrm{c})$ (1970).

77. See Shulman, Civil Liability and the Securities Act, 43 YALE L.J. 227, 249 (1933) (calling the dispensation with the need for privity "the most striking innovation" of the section).

78. If the plaintiff acquires the security after the issuer has made generally available to its securities holders an earnings statement covering at least a twelve month period subsequent to the registration statement's effective date, then the right to recovery is conditioned on the plaintiff's proof that the security was acquired in reliance on the alleged misrepresentation. However, proof of the requisite reliance may be made without a showing that plaintiff read the registration stateinent. Securities Act of $1933 \S 11(\mathrm{a}), 15$ U.S.C. $\$ 77 \mathrm{k}(\mathrm{a})(1970)$. In the absence of this special situation a clainant must only avoid the defense that he knew of the claimed defect in the registration statement at the time he bought the security. Id. 
named as "experts" in the registration statements, ${ }^{70}$ and to impose broad liability for negligent misrepresentations made by such professionals. Liability may be avoided only by a showing of exercise of due diligence under the circumstances. ${ }^{80}$

In the leading case of Escott v. BarChris Construction Corp. ${ }^{81}$ the federal district court held that, while the defendant accounting firm was liable under section 11 for negligence in the conduct of its review of the issuer's financial position, the defendant attorney who served as a director of the issuer and who prepared the registration statement was not liable as an expert for material misstatements arising from his negligence in putting the registration statement together, since the section does not contemplate expert liability for lawyers who supervise registration statement filings. ${ }^{82}$ The defendant attorney was, however, held liable to plaintiffs under section 11 in his capacity as director. Though the BarChris holding provides protection from liability for couusel who generally supervise preparation of the registration statement, the case clearly does not protect attorneys in the instances already referred to where counsel is named

79. See id. $\$ 77 \mathrm{k}(\mathrm{a})(4)$.

80. See Securities Act of $1933 \S 11$ (b)(3)(B), 15 U.S.C. $\$ 77 \mathrm{k}(\mathrm{b})(3)(B)$ (1970).

81. 283 F. Supp. 643 (S.D.N.Y. 1968). For the definitive treatment of the case, see Folk, Civil Liabilities Under the Federal Securities Acts: The BarChris Case, 55 VA. L. Rev. 1, 199 (1969). Coinmentaries on the case are collected and discussed in Keefe, Boils and Bubble, Bowling BarChris, 56 A.B.A.J. 92 (1970).

82. The sound basis for the court's failure to subject the lawyer to an expert's liability was explained by Professor Donald Schwartz:

One of the outside directors, I think this is most interesting for us, was the attorney who actually prepared the registration statement. The first thing the other defendants said was, "Your honor, I intend to come clean and tell the truth; he did it." Their defense was that he had overall responsibility for preparing the registration statement and, therefore, was an expert within the meaning of the 1933 Act. The significance of that is that section 11 "contains a provision to the effect that if a portion of a prospectus has been prepared by an expert, the non-experts can rely on him unless they have good reason for thinking he has not done the job properly, or that there is some inaccuracy." They said, "We relied on this expert. Therefore he is liable for everything and we are liable for nothing."

Judge McLean rejected this contention; he found the lawyer is not an expert, at least with regard to the entire registration statement. There may be matters where the lawyer is an expert. For example, if there is a tax opinion expressed. I think others can safely rely on that without fear of liability on their own part. The expert takes responsibility for that particular type of assertion.

The concept of expertise cannot apply to the whole registration stateinent, or everybody would let someone else bear the brunt for him, which would flout the scheine that Congress had in mind. How to Go PUBLIC, supra note 14, at 304-06.

For further views on the scope of an attorney's liability as an expert under section 11, see BarChris Institute, supra note 67, at 555-56, 591, 676 (reinarks of Arnold Daum, Jack M. Whitney II, and Milton V. Freeinan, respectively). 
in the registration statement in connection with opinions rendered on such technical matters as tax consequences br the validity of the securities issued..$^{83}$ This type of "expert" opinion can give rise to section 11 liability.

In contrast with expert opinions is the opinion rendered by counsel in connection with a public offering which states that the registration statement has been reviewed in an agreed-upon manner ${ }^{84}$ and that counsel has no reason to beheve that the registration statement is misleading in any material respect. Although BarChris indicates that there is no section 11 liability for such opinions, there is still the question of counsel's exposure for common law malpractice as a result of his lack of diligence in the rendition of this type of opinion where counsel is listed in the prospectus as having "passed on" the registration statement for the company. While it has been argued that no liability should attach even where counsel is listed in the prospectus because investors do not rely on counsel's identity in making their investment decisions, ${ }^{85}$ it has also been pointed out that, as in the municipal bond case, counsel are listed in the prospectus "on the theory that their names and standing have some impact on the judgment of investors as to whether or not to purchase the security." ance on counsel by investors, it would seem that the existence or nonexistence of reliance by a third party is a factual matter best left for resolution upon consideration of individual parties' claims, and not a matter which should be resolved by a blanket finding of nonreliance or absence of duty.

\section{Title Opinions}

In addition to the municipal bond and public offering cases, there are other common legal opinion settings that could give rise to liability to third parties for negligent malpractice should a court elect

83. See BarChris Institute, supra note 67 , at 555-56, 591, 676 (remarks of Arnold Daum, Jack M. Whitney II, and Milton V. Freeman, respectively).

84. For a statement on the need to reach clear agreement on the scope of counsel's responsibilities at the outset, see id. at 654 (remarks of David S. Henkel).

85. Address by Francis $M$. Wheat, the Fourth Annual Institute on Securities Regulation, New York City, Nov. 3, 1972.

86. When Corporations Go Public 251 (C. Israels \& G. Duff ed. 1970). See also Transcript, supra note 14 , at 139, 144. It should be noted that the argument has been made that remedial claims by an injured shareholder may include allegations under section $10(\mathrm{~b})$ and rule $10 \mathrm{~b}-5$, as well as section 11 and common law charges. See id. at 148-59. Opinion letter claims under securities laws civil liability provisions other than section 11 are discussed in the context of opinions freeing unregistered stock for sale at pp. 395-411 infra. 
to step beyond the privity barricade. A prime example is the opinion on the state of title similar to the one issued in the Ward case. ${ }^{87}$ Given the common expectation of lawyers that opinions concerning the state of title property will be relied upon by third parties, ${ }^{88}$ a future court may well decide to adopt the view advocated by the dissent in Ward and allow recovery for negligent malpractice by a reliant lender or purchaser whose precise identity was unforeseen at the time the opinion was rendered. Because of the custom and usage surrounding the rendition of a title opinion, a court could well justify a holding of liability even where the lawyer was not told the exact purpose to which the opinion would be put; it would suffice for the plaimtiff to belong to a class known to rely customarily on such opinions.

\section{Audit Letters}

In connection with the audit of a public company, accountants often seek lawyers' opinions directed toward issues requiring special legal expertise such as the company's freedom from material contingent liabilities (as, for example, where title to a significant annount of real estate held by a company is in doubt ${ }^{89}$ and the materiality of pendimg litigation. What is the scope of the attorney's liability to third parties where the erroneous conclusion of a negligently rendered opinion to the accountant is eventually reflected in the coinpany's certified financial statements? A court willing to make the same sort of public policy judgment arrived at in Ultramares logically would decide not to hold the lawyer liable for simple negligence in assessing the status of the company's contingent liabilities where it would not by parity in reasoning hold the accountant liable for negligence in assessing the status of the company's current or longterm liabilities. By the same token, if a court were to reject Ultramares and impose liability on the accountant for negligence, it should have little difficulty holding the negligent attorney similarly hable..$^{90}$

87. See notes 33-36 supra and accompanying text.

88. Annot., supra note 36 , at 1200 .

89. A recent and increasing tendency for law firms to adopt a policy of refusing to express opinions on their client's contingent liabilities has been observed. The reason, of course, is the fear of turning a contingent liability into an existing one by calling a problem to the attention of plaintiffs' lawyers. Address by Francis $M$. Wheat, supra note 85.

90. Apart from negligence liability, an attorney's judgment set forth in an audit letter that is later reflected in the company's certified financial statements used in a prospectus will afford a basis for liability on the part of the lawyer under section 11, provided he consents to liaving his name connected with the rep- 


\section{Opinions on the Sale of Unregistered Stock}

The final type of legal opinion that is taken up in this analysis of different opinion letter settings concerns the use of opinions to facilitate the sale of unregistered stock. Primary emphasis in the following discussion is on sketching a number of the considerations that may come into play in assessing counsel's potential exposure for a faulty stock sale opmion.

The statutory context. Section 5 of the $1933 \mathrm{Act}^{91}$ broadly prohibits the use of the mail or facilities of imterstate commerce to sell a security unless a registration statement filed with the SEC is in effect, and any person claiming the benefit of an exemption to the filing requirement has the burden of proving his right to it. ${ }^{92} \mathrm{Be}$ cause of the highly technical nature of the Act, persons faced with the threat of potential liability in connection with the sale of unregistered stock have generally adopted the practice of requiring those involved in such stock transfers to present opinions of counsel stating that the shares may be sold without registration.

Thus, where a shareholder desires to sell unregistered stock, the issumg corporation may demand an opinion by or acceptable to its counsel to the effect that the exemption relied on in issumg the shares without registration will not be lost by reason of the sale. ${ }^{93}$ In another case, a person who wishes to dispose of shares taken in a private placement may require his transferee to present an opinion of counsel to the effect that the transferee is not intent on engaging in an illegal distribution of the stock, since this could result in both

resentation in the registration statement. See notes 74-83 supra and accompanying text. Cohen \& Wheat, Professional Responsibility, reprinted in PLI, FouRTa ANNUAI INSTITUTE ON Securrites Regulation 75, 81 (1972). For a more detailed discussion of audit letters, see Deer, Lawyers Responses to Auditors' Requests for Information, 28 Bus. LAw. 947 (1973).

91. 15 U.S.C. \& $77 \mathrm{e}(1970)$.

92. See, e.g., SEC v. Ralston Purina Co., 346 U.S. 119 (1953); Edwards v. United States, 312 U.S. 473 (1941); SEC v. Culpepper, 270 F.2d 241 (2d Cir. 1959); Gilligan, Will \& Co. v. SEC, 267 F.2d 461 (2d Cir. 1959).

93. An opinion of this sort is involved in the National Student Marketing litigation. As discussed at pp. 421, 426-29 infra, the law firm of Lord, Bissell \& Brook issued an opinion letter to National Student Marketing Corp., stating that certain insiders of Interstate National Corp. could sell without a registration statement shares of NSMC which they acquired by merger. The exenption relied on was that set forth in rule 133, 17 C.F.R. $\$ 230.133$ (1972), which provides generally that the registration provisions of section 5 are not applicable to securities issued in certain business combinations of a type specified in the rule. Further, the rule permits certain limited resales of those securities. Other than registration, rule 133 provides no exceptions or exemptions from any other provisions of the federal securities laws, including the antifraud provisions. 
sellers being held in violation of the Act as "statutory underwriters." ${ }^{24}$ Broker-dealers similarly use legal opinions for protection froin charges that they acted in the capacity of statutory underwriters in connection with the distribution to the public of substantial blocks of unregistered stock. ${ }^{95}$

Securities laws exposure. From the earlier discussion of a lawyer's common law malpractice exposure for his legal opinions, it sliould be clear that counsel runs a substantial risk of malpractice liability to persons for whose reliance a negligently prepared unregistered stock sale opinion is intended. In this section, the general parameters of a lawyer's potential securities laws liability for unregistered stock sale opinions will be considered. Following an introductory analysis of the possible types of actions an opining lawyer may be called on to defend under the securities laws, consideration is given to three key areas of concern in assessing the lawyer's exposure qua lawyer under the securities laws for an erroncous opinion. The first two areas concern the extent of a lawyer's obligation to see that his opinion is right on both the facts stated and the law applied. The third area for consideration is the principle that the lawyer's exposure for his actions in a legal capacity is dependent upon his acting as a "participant" im an illegal transaction.

(1) Gradations in liability. Three types of actions may be filed against a lawyer charged with violating the securities laws. First, under rule 2(e) of its Rules of Practice, ${ }^{96}$ the SEC is einpowered to institute disciplinary proceedings against professionals who, among other things, are believed by the Commission "to have engaged in improper or unethical professional conduct."

94. 15 U.S.C. $\& 77 \mathrm{~b}(11)$ (1970). The section defines an underwriter as, inter alia, "any person who ... offers or sells for an issuer in connection with the distribution of any security, or participates or has ... a participation in any such undertaking ...." The SEC is of the view that the concept of "distribution" is vital to interpreting the meaning of "underwriter." SEC Securities Act Release No. 5223 (Jan. 11, 1972) (adoption of rule 144). In brief, the Commission feels that the salient factors to be considered in evaluating whether a person has engaged in a distribution are: (1) whether there is "adequate current information concerning the issuer"; (2) the existence of a "holding period prior to resale"; and (3) the "impact of the particular transaction or transactions on the trading markets." Id. Where section 4(1) of the 1933 Act, 15 U.S.C. $\$ 77 \mathrm{~d}(1)$ (1970), is used as a basis for exemption from registration, it is imperative that the seller not be an "underwriter," for the section only exempts from registration "transactions by any person other than an issuer, underwriter or dealer."

95. The use of legal opinions by broker-dealers in the context of section 4(1) exemptions is discussed in SEC Securities Exch. Act Release No. 6721 (Feb. 2, 1962).

96. 17 C.F.R. $\$ 201.2(\mathrm{e})(1970)$.

97. Id. § 201.2(e)(1). See generally Comment, supra note 5. 
the sanctions that may be imposed upon an attorney found liable is suspension of the right to practice before the Commission. The second type of proceeding which may be brought against the attorney is an action by the SEC for a civil injunction restraining the defendant attorney from further violations. The National Student Marketing litigation mentioned in the introduction is such a case. This type of action may serve as a basis for a later rule 2(e) proceeding and may result in a contempt of court finding in the event of a subsequent securities laws violation by the enjoined lawyer..$^{98}$ The third type of action that may arise from a lawyer's violation of the securities laws is the familiar civil action instituted by private litigants. This type of remedy could come into play where counsel's opinion furthers an illegal scheme involving the sale of unregistered stock. In such a case counsel might be called on to defend suits brought under section 17(a) of the $1933 \mathrm{Act}^{99}$ and section 10(b) of the 1934 Act $^{100}$ and rule 10b-5 thereunder. ${ }^{101}$ Civil actions may be brought under those sections for redress of fraud perpetrated in the sale of securities. ${ }^{102}$ Section 12(1) of the 1933 Act $^{103}$ provides for civil recovery froin sellers who violate section 5 and has come imto play in unregistered stock sale suits against lawyers, ${ }^{104}$ but the section does not appear to hold much promise for plaintiffs seeking to recover from lawyers in opinion letter cases absent facts showing that the defendant attorney was either a seller or solicited the illegal sale. ${ }^{105}$

While the same sort of malfeasance may well expose an attorney to an adverse judgment in either the rule 2(e) disciplinary pro-

98. See note 4 and text accompanying notes 3-4 supra.

99. 15 U.S.C. $\$ 77 \mathrm{q}(\mathrm{a})(1970)$.

100. $I d . \$ 78 \mathrm{j}(\mathrm{b})$.

101. 17 C.F.R. $\$ 240.10 \mathrm{~b}-5$ (1972).

102. The two 1934 Act provisions are broader in scope, covering fraud perpetrated in connection with stock purchases as well as sales.

103. 15 U.S.C. $\& 77 l(1)(1970)$.

104. In Wonneman v. Stratford Sec. Co., [1957-1961 Transfer Binder] CCH FED. SEC. L. REP. If 91,034 at 93,458 (S.D.N.Y. 1961), defendant attorney was charged with assisting in the illegal sale of unregistered securities in violation of section 12(1). At trial it was shown that the lawyer's only contact with the transaction in question involved his giving an oral opinion to one of the sellers to the effect that the stock could be sold absent registration. The court held that these facts were sufficient for venue purposes, but madequate to make out a winning case that the defendant attorney was a "seller" within the intent of the section. Cf. Nicewarner v. Bleavins, 244 F. Supp. 261 (D. Colo. 1965) (holding that an attorney who had drafted assignments later found to be securities illegally sold without registration was not a seller within the terms of the section since he had not actually sold or solicited the sale of the securities).

105. See Nicewarner v. Bleavins, 244 F. Supp. 261, 266 (D. Colo. 1965). 
ceeding, injunction action, or private damage action, this is not to say that there are no tangible gradations in the standards of conduct which the different remedial frameworks encompass. To the contrary, the degree of culpability giving rise to a rule 2 (e) action by the Commission is arguably less than might be required to support an injunction action. ${ }^{108}$ Further, the level of culpability sufficient to sustain entry of an injunction in favor of the SEC will not necessarily support a judgment in a damage action brought by a private investor. ${ }^{107}$ Within these categories, however, there is obviously still much room for the exercise of discretion.

Apart from the general stateinent that the burden of establishing liability is more easily sustained in a rule 2 (e) proceeding than in civil litigation, it is liard to find articulated in the cases useful standards for gauging the exposure of professionals for alleged wrongs in the securities law field. One reason for this void is, as pointed out in the next section, the paucity of decisions that consider the exposure of a lawyer in his capacity as a lawyer without intermingling judgments on the defendant lawyer's participation in the wrongdoing in soine other capacity. Another reason why the precedents may be somewhat difficult to unscramble is related to the labels used by the courts in deciding the standard of conduct required to establish antifraud liability in an action for damages under section 10(b) and rule 10b-5. For example, the Second and Fiftl Circuits apparently require some form of "scienter" to uphold a judgment of liability in a 10b-5 damage action, although the requisite intent can probably be deduced from gross negligence or recklessness. ${ }^{108}$ The Seventh, Eighth, Ninth and perliaps Tenth Circuits liave given some indication that scienter is not a requirement under $10 \mathrm{~b}-5$, thus paving the way for a finding of liability in the event of neghigence. ${ }^{100}$

106. See Transcript, supra note 14 , at $123-24$ (remarks of Professor Robert H. Mundheim).

107. See, e.g., SEC v. Capital Gains Research Bureau, 375 U.S. 180, 193 (1963); Hanly v. SEC, 415 F.2d 589, 596-97 (2d Cir. 1969); SEC v. Great Am. Indus., Inc., 407 F.2d 453, 460 (2d Cir. 1968), cert. denied, 395 U.S. 290 (1970).

108. Herpich v. Wallace, 430 F.2d 792 (5th Cir. 1970); SEC v. Texas Gulf Sulphur Co., 401 F.2d 833, 867-68 (2d Cir. 1968), cert. denied, 394 U.S. 976 (1969).

109. Vanderboom v. Sexton, 422 F.2d 1233 (8th Cir.), cert. dcnied, 400 U.S. 852 (1970); Stevens v. Vowell, 343 F.2d 374 (10th Cir. 1965); Kohler v. Kohler Co., 319 F.2d 634 (7th Cir. 1963); Ellis v. Carter, 291 F.2d 270 (9th Cir. 1961). The Tenth Circuit's decision in Stevens should be compared with the more recent and less liberal holding by the court in Mitchell v. Texas Gulf Sulphur Co., 446 F.2d 90 (10th Cir.), cert. denied, 404 U.S. 1004 (1971). See generally Bucklo, Scienter and Rule 10b-5, 67 Nw. U.L. REv. 562 (1972). 
While there are colorable reasons that may be cited in opposition to any securities law antifraud damage verdicts against lawyers whose malpractice ineets only a negligence standard, ${ }^{110}$ in actual practice it will likely matter little whether a court demands proof of

110. For one thing, it may be argued that the states have a clear and strong interest in governing the conduct of attorneys within their borders from the time character references are first filled out in connection with completion of bar examination applications through retirement, and that this important state interest should not yield to federal intervention without good reason. Such federal intervention would come into play where, for example, a federal court finds counsel liable under the securities laws for "negligence" by reason of his failure to undertake an investigation of facts presented by his client, with the duty to investigate forming no part of the relevant state's malpractice law. Significant support for this view that federal intervention may be improper in such circumstances is found in the area of corporate fiduciary responsibilities where there is a comparable state interest. In judging breach of fiduciary duty claims alleged to arise under the securities laws, the federal judiciary has been known to refrain from usurping the province of the states to develop their own code of conduct for fiduciaries. For the reasoning underlying this exercise of federal restraint, see Kaminsky v. Abrams, 281 F. Supp. 501 (S.D.N.Y. 1968), where the court stated:

The fiduciary responsibilities of corporate directors are ... defined by the law of the state of incorporation. Federal legislation supersedes state corporate law remedies only to the extent of any direct conflict between the two .... and unless a matter is clearly covered exclusively by federal statute it is deemed to be subject to state law. If Congress had intended to preempt the entire field, "so revolutionary a federal intervention," Loss says, "would presumably have been clearly expressed," II Loss, Securities Regulation 903. Thus, although federal securities laws have been construed broadly in the light of their remedial purposes ... they remain "incomplete and interstitial" in nature ... and do not represent a federal corporate law with respect to responsibihity of officers and directors that has supremacy over state law, which Congress has never adopted. Id. at 504-05.

Accord, Herpich v. Wallace, 430 F.2d 792, 809 (5th Cir. 1970). See Christophides v. Porco, 289 F. Supp. 403, $405-06$ (S.D.N.Y. 1968); Barnett v. Anaconda Co., 238 F. Supp. 766, 770 (S.D.N.Y. 1965). By the same token, it might be argued that Congress has never adopted a plan that would permit federal courts to usurp the state function of overseeing standards governing simple negligence (as opposed to fraud) by professionals. It would seem that the SEC has power already under rule 2(e) of its Rules of Practice to discipline professionals who engage in unethical or improper professional conduct or wilfull fraud. See Colnment, supra note 5. There is no apparent reason for the federal judiciary to insert itself into the negligent malpractice matrix under the guise of making determinations under "antifraud" provisions. But cf. TransCript, supra note 14, at 40 , where it is noted that "no matter what's in the Code, in the state statutes or in the state cases, federal courts will end up applying federal rules in [the attorneyclient relationship] area."

Another reason why courts should be reluctant to award recovery under the antifraud provisions for negligent malpractice is related to the major policy determination made in Ultramares of limiting suits brought by a member of a broad class of allegedly injured persons. If this policy had vitality in 1931 when Ultramares was decided, it should have far greater force in this day of the ubiquitous class action law suit in securities law cases.

Class actions seeking recovery at common law for negligent malpractice do not pose a grave threat to professionals for a number of reasons. First, very few 


\section{negligence, gross negligence or scienter. A court or jury convinced} that a defendant attorney ought to be held liable for an incorrect

states have embraced the class action as a legitimate device for awarding mass recovery in cases where each class member has a separate claim for relief. $C f$. Eckhardt, Consumer Class Actions, 45 Notre DAME LAw. 663 (1970); Homburger, State Class Actions and the Federal Rule, 71 Colum. L. REv. 609 (1971); Wall Street J., May 14, 1970, at 10, cols. 1-2. Second, class action relief in federal diversity cases is limited by the requirement of Snyder v. Harris, 394 U.S. 332 (1969), that each class member have a claim for relief in excess of $\$ 10,000$. A recent case discussing this problem is Zahn v. International Paper Co., 469 F.2d 1033 (2d Cir. 1972). Third, even where a state court might be willing to entertain the suit, it may very well be uuwilling to award relief to nonresident class members. See Anthony v. General Motors Corp., No. 959,058 (Los Angeles Calif. Super. Ct., Dec. 22, 1971); Robimer v. General Motors Corp., No. 172,865 (Wayne Cty. Mich. Cir. Ct., July 22, 1971) (both cases involve refusals by courts to allow nationwide class actions in products liability cases). Finally, there is a serious question whether the character of a malpractice suit based on alleged negligence lends itself to class action treatment. Because the nature of the wrong claimed is negligence, each alleged class member would be required to establish injury proximately caused by the asserted malpractice just as would be the case if a class member sued individually. See, e.g., Note, Attorney Malpractice, supra note 23 , at 1307 . This need for individual proof by each class member could very well disqualify the suit from class action consideration by making the trial protracted and unmanageable. See Schaffner v. Chemical Bank, [1971-1972 Transfer Binder], CCH FED. SEC. L. REP. If 93,403 (S.D.N.Y. 1972); Cannon v. Texas Gulf Sulphur Co., 53 F.R.D. 216 (S.D.N.Y. 1971). On the other hand, a ruling by the court that the burden of individual proof could be lessened or dispensed with altogether because of the class action character of the litigation would amount to modification of the requirements for a substantive cause of action by use of a procedural rule. This development is offensive to our common law tradition and could very well deprive a defendant of his fourteenth amendment right to assert individual defenses which he might establish if he could confront each class member individually. See American Surety Co. v. Baldwin, 287 U.S. 156, 168 (1932) ("Due process requires that there be an opportunity to present every available defense.").

In sum, there is a good basis for belief that in malpractice suits alleging common law negligence, the ascendancy of the class action device does not pose a serious threat to the policy recognized in Ultramares. This would manifestly not be the case should the antifraud provisions of the securities laws provide a haven for malpractice actions based on negligent misconduct. Resort to the class action device is well-recognized as a means of securing redress for alleged violations of the securities laws. See Annot., Propriety, Under Rules 23(a) and 23(b) of the Federal Rules of Civil Procedure, as Amended in 1966, of Class Action for Violation of Federal Securities Laws, 9 A.L.R. Fed. 118 (1971); cf. "ADAM SMITH," SUPERMONEY 166-69 (1972). This development makes likely the threat of massive exposure of professionals for simple negligence if courts accept a diluted definition of fraud in malpractice cases brought under the securities laws. It may be argued that under these circumstances, allowance of class actions under the securities laws would clearly contravene the policy inherent in Ultramares of limiting the vistas of professional liability where there is no inference of fraud. Whether the policy of Ultramares deserves to be protected from such inroads is, of course, a different matter. 
opinion can easily categorize his performance as negligent if that will suffice, or grossly negligent if that standard of misconduct is necessary to support a violation of the securities laws in the particular jurisdiction.

(2) The lawyer's responsibility to be right on the facts. In 1962 the SEC set forth the standard of care it felt was required of an attorney called on to issue an unregistered stock sale opinion:

Obviously, an attorney's opinion . . . is worthless . . . if unspecified but vital facts are not considered. Because of this, it is the practice of responsible counsel not to furnish an opinion ... unless such counsel have themselves carefully examined all of the relative circumstances and satisfied themselves, to the extent possible, that the contemplated transaction is in fact, not a part of an unlawful distribution. Indeed, if an attorney furnishes an opinion based solely upon hypothetical facts which he made no effort to verify, and if he knows that his opinion will be rehed upon as the basis for a substantial distribution of unregistered securities, a serious question arises as to the propriety of his professional conduct. ${ }^{111}$

The Commission's pointed comment questioning the propriety of the opining lawyer's professional conduct strongly indicates its willingness to institute proceedings against wayward counsel under rule 2(e). Assessing whether conduct that the SEC iniglit label "negligent" or "unprofessional" constitutes a basis for securities laws hability is, as was noted, a task not made easier by the scarcity of case law dealing with the issue. While there is no great shortage of cases and admimistrative actions finding actionable misconduct on the part of counsel in connection with fraudulent schemes furthered by the issuance of legal opimions, ${ }^{112}$ the attorney is often so closely asso-

111. SEC Securities Act Release No. 4445 (Feb. 2, 1962).

112. United States v. Benjamin, 328 F.2d 854 (2d Cir. 1964) ("abundant evidence" that defendant attorney issued opinions freeing unregistered stock for sale when he knew registration was required); SEC v. R.D. Philpot Indus., Inc., 73 Civ. 543 (S.D.N.Y., filed Feb. 5, 1973), noted in N.Y.L.J., Feb. 6, 1973, at 1, cols. 4-5; United States v. Hamilton, No. 71 Cr. 780 (S.D.N.Y., Sept. 27, 1972), noted in Wall Street J., Sept. 28, 1972, at 3, col. 2; SEC v. Fields, 71 Civ. 5416 (S.D.N.Y., Feb. 7, 1972), noted in Wall Street J., Dec. 14, 1971, at 14, col. 2; SEC v. Century Inv. Transfer Corp., [1971-1972 Transfer Binder] CCH FED. SEC. L. REP. T 93,232 (S.D.N.Y. 1971); Marshall I. Stewart, SEC Securities Act Release No. 4829 (April 29, 1966) (rule 2(e) proceeding against defendant attorney for, inter alia, issuing groundless opinion letters as to availability of certain securities laws exemptions); Morris Mac Schwebel, 40 S.E.C. 347 (1960) (rule 2(e) proceeding permanently disqualifying defendant attorney from practicing before the Commission for, inter alia, issuance of opinions freeing unregistered stock for sale when he knew or should have known registration was required). A non- 
ciated with the wrongdoing that he is held hable as a primary wrongdoer in some other capacity than as a lawyer.

A recent and very notable exception to this type of case is $S E C$ v. Spectrum, Ltd. ${ }^{113}$ Spectrum involved the application to a concrete factual setting in an injunction action of the position taken by the SEC in its 1962 release that some minimal level of factual inquiry is required of counsel who issue opinions freeing unregistered stock for sale. : The defendant attorney in Spectrum was hired by one or more Spectrum Ltd. insiders of uncertain identity for the purpose of writing an opinion assessing the transferability lof over 2 million shares of unregistered stock. The lawyer had had no previous dealings of any substance with Spectrum or its insiders before undertaking to write the first formal opinion letter of his ten-year legal career in order to "free up" the stock. The shares in question had been the subject of an opinion issued by Spectrum's corporate counsel before the defendant attorney arrived on the scene. In that opinion Spectrum's counsel had examined the transferability of some 4.6 million shares and decided that the representations of Spectrum insiders warranted 2.6 million shares being restrieted. The company's lawyer would have allowed the remaining 2 million shares to be "'freed-up' . . . merely because he had no documentation . . . to the contrary."114 Subsequent to rendering this opinion, the corporation's counsel wrote a letter to Spectrum's president listing the shareholders who held freely transferable stock.

After he was approached and asked to write an opimion freeing the 2 million shares for sale, the defendant attorney met with Spectrum's corporate counsel. At that meeting the company's regular lawyer allegedly gave four reasons why he did not want to write an opinion letter for the defendant's client: (1) as company counsel he had no duty to do so; (2) he had already prepared an earlier opm-

opinion letter case worthy of note is SEC v. Frank, 388 F.2d 486 (2d Cir. 1968). In Frank, the defendant attorney was charged with having drafted a prospectus that allegedly contained false representations concerning the efficacy of a chemical additive developed by the issuer. In defense it was argued that the attorney was only a scrivener and that any liability should be assessed against management whose representations the attorney merely placed "m proper form," not his own. 388 F.2d at 488 . The court rejected this position out of hand:

A lawyer has no privilege to assist in circulating a statement with regard to securities which he knows to be false simply because his client has furnished it to him. ...

A lawyer, no more than others, can escape hability for fraud by closing his eyes to what he saw and could readily understand. Id.

113. [1972-1973 Transfer Binder] CCH FED. SEC. L. REP. If 93,631, at 92,864 (S.D.N.Y. 1972).

114. Id. at 92,866 . 
ion concluding that the stock was transferable; (3) he wanted to avoid binding himself to the financial community; and (4) he suspected that the stock the defendant had been asked to free would be traded by a control person in violation of the securities laws. ${ }^{115}$ This last representation allegedly made to the defendant was found by the court to be the "only evidence imputing to [defendant's] knowledge of any possible illegality"116 and was eventually evaluated as hardly credible. ${ }^{117}$

Employing copies of agreements for the issuance of the shares under consideration and using the opinion letter and shareholder list earlier prepared by Spectrum's counsel in what appears to have been a cut-and-paste fashion, the defendant reached the "opinion" that the stock was not required to be registered under the securities laws. Though the narrow scope of the defendant's factual study was not stated in the opmion, the cover letter transmitting the opinion pointed out that the defendant had made no factual investigation and was relying only upon the facts as represented to him. Moreover, the transmittal letter stated that the opinion was for the personal use of the addressee, one Doyen, and was not to be given to any broker or dealer for the purpose of imducing the sale of unregistered Spectrum shares.

The defendant's opinion having proved to be groundless, the SEC sought an injunction to restrain him from violating the securities laws. The Commission asserted that the defendant had violated the 1933 Act directly by furthering the sale of unregistered shares as a statutory underwriter in violation of section $5,{ }^{118}$ and also indirectly by having aided and abetted ${ }^{119}$ a scheme fraudulent under section 17(a), section 10(b) and rule 10b-5 (consisting of the unlawful sale of unregistered Spectrum shares to pay off personal debts owed by insiders).

The court refused to find for the SEC on either charge. The SEC's claim that the defendant was an underwriter was rejected on the ground that there was "no evidence that any such unregistered securities were sold on the basis of the letter,"120 and the court

115. Id.

116. $I d$.

117. Id. at 92,867 .

118. See note 94 supra.

119. For the definitive treatment of aider and abettor liability, see Ruder, Multiple Defendants in Securities Law Fraud Cases: Aiding and Abetting, Conspiracy, In Pari Delicto, Indemnification, and Contribution, 120 U. PA. L. Rev. 597 (1972).

120. [1972-1973 Transfer Binder] CCH FED. Sec. L. REP. If 93,631, at 92,867. 
found no authority for the view that "mere preparation of an opinion letter is sufficient to make the preparer an underwriter." ${ }^{121}$ The Commission's "aider and abettor" claim was likewise rejected. In brief, for aider and abettor liability to exist under the securities laws, three things must happen: first, there must be an independent wrong; second, the alleged aider and abettor must have "knowledge" of the misconduct (which may be shown by reckless conduct or by inference);122 and third, he must give some quantum of assistance to the wrongdoing. ${ }^{123}$ Finding neither direct nor circumstantial evidence of knowledge of the improper scheme, the court held that, while defendant "may have been guilty of some negligence, there is insufficient evidence to support anything more serious than that." ${ }^{24}$ The court's refusal to place the defendant's actions in the garb of stock fraud is understandable in light of its clear behef that

121. Id.

122. Ruder, supra note 119, at 638. Cf. United States v. Sarantos, 455 F.2d 877, 880-81 (2d Cir. 1973), which is briefly discussed at text accompanying notes 188-90 infra. In the case of SEC v. First Sec. Co., 463 F.2d 981 (7th Cir.), cert. denied, 409 U.S. 880 (1972), the Seventh Circuit seemed to cast doubt on the vahidity of the knowledge requirement by holding a brokerage firm liable under the securities laws as an aider and abettor of the fraud perpetrated by its deceased president. The firm had no knowledge of wrongdoing, and the only assistance it could be said to have given the wrongdoing was in representing that its president had provided sound investment counsel and acquiescing in the president's "enforcement of a rule regarding the opening of mail which was antithetical to the prevention of frauds of the type which occurred." 463 F.2d at 988. Apparently the court felt that the firm's acquiescence in the president's mail opening rule constituted sufficient recklessness to satisfy the knowledge requirement for aider and abettor liability. While there is merit to the court's additional findings that the firm was liable as a principal under agency theory, as a controlling person under the section 20(a) of the 1934 Act, 15 U.S.C. $\$ 78 t(a)$ (1970), and for violation of rule 27 of the National Association of Securities Dealers' Rules of Fair Practice, CCH NASD MANUAL II 2177 (1972), it can be argued that the court missed the mark in its aider and abettor analysis. As one respected commentator has pointed out, brokerage firms owe direct obligations to the public, including the duty to supervise their employees, and breach of such duties would seem to give rise to direct, not secondary, liability. Ruder, supra note 119 , at 599-600, 645-46. On the other hand, it has been suggested that the area of aider and abettor liability based on participation with "less than actual knowledge" is destined to be "the focal point for expanding liabilities" under the securities laws. TRANSCRIPT, supra note 14, at 265-66 (remarks of Martin Lipton). If so, the seemingly tame brand of recklessness found to be a sufficient basis for liability in First Securities raises some interesting questions for lawyers. For example, does a law firm that fails to establish adequate procedures for review of its lawyers' work run the risk of aiding and abetting a securities law violation committed by one of its lawyers? Some general guidelines drafted to assist attorneys in avoiding this problem in an opinion letter setting are set forth at pp. 433-39 infra.

123. Ruder, supra note 119 , at 630 .

124. [1972-1973 Transfer Binder] CCH FED. SEC. L. REP. ๆ 93,631, at 92,868. 
the SEC had pursued the wrong man. Speaking of Spectrum's corporate counsel who had drafted the opinion originally freeing the stock "merely because he had no documentation . . . to the contrary," 25 the court stated that he "must consider himself indeed fortunate not to be named as a defendant herein . . . ."128

We see in Spectrum a good deal of compassion for misled counsel. The court's finding of "soine negligence" by the defendant is clear recognition that his conduct did not meet the standard of care established by the SEC in its 1962 release. Yet the court held the degree of recklessness required to tip the degree of care exhibited into the fraud category to be absent. The decisive factor here apparently was the defendant's ability to point to the cover letter accompanying his opinion as proof that sale of the securities in reliance on the opinion was not anticipated. A less lenient judge might have wondered to what other use the defendant reasonably expected his opinion to be put.

The defendant in Spectrum obviously had a very close call. The court's comment regarding the likely liability of Spectrum's counsel strongly suggests that a lawyer's rendition of an opinion freeing stock for sale siniply because insiders have failed to volunteer a reason for restriction can amount to misconduct punishable under the securities laws. Some inquiry is clearly required by the SEC's release, but where the limits are to be drawn is a matter that must depend on the facts of the particular situation. ${ }^{127}$ An opinion requested by a long-time client having an unblemished record of fair disclosure of all salient facts will likely require a good deal less in the way of independent imvestigation than an opinion rendered on behalf of a new client or a client known to be in financial difficulties or known to have been less than candid in his disclosure of factual matters in the past. Further, it would seein to be a sound policy to point out specifically in the body of the opinion letter itself the scope of the investigation conducted and the extent to which representations of others are relied upon.

Since the defendant's opinion was judged as an original work product, the court in Spectrum never took up the issue of counsel's exposure for relying on an erroneous opinion prepared by another

125. Id. at 92,866 .

126. Id. at 92,868 .

127. A general discussion of the lawyer's duty to investigate facts is set forth in TranscrIPT, supra note 14, at 125-31, 176-78. In the course of the discussion, securities lawyer A. A. Sommer expressed his view that "[t]he language of Rule $10 \mathrm{~b}-5$ can certainly be construed to regard a lawyer who renders an opinion without reasonable investigation as engaged in a deceptive act or practice." Id. at 177. 

tion by an attorney constituted negligent malpractice. Recall also, however, that California is the leading state to have abandoned the privity requirement for attorneys' liability to third parties. It may very well be that as the vistas of liability have expanded in California, the boundaries of what is a substantive wrong have shrunk. Perhaps this same phenomenon will soon appear on the securities laws scene if, indeed, it has not already arrived in the form of Spectrum.

In any event, there are minimal levels below which conduct may not sink without becoming too heedless to be called mere negligence. In distinguishing the situation in Ultramares, Judge Cardozo provided the example of an audit certificate from which it could be inferred that the preparer had "no genuine belief in its accuracy."132 SEC v. Century Investment Transfer Corp..$^{133}$ is an opinion letter case involving similarly indefensible conduct.

In Century Investment Transfer, the SEC based its charges of violation of the antifraud provisions of section $17(\mathrm{a})$, section $10(\mathrm{~b})$, and rule $10 \mathrm{~b}-5$ on the defendant attorney's issuance of opinion letters saying that unregistered stock could be sold despite clear statutory language to the contrary. In summing up its view of the defendant attorney's misconduct, the court stated:

Caldwell's preparation of misleading opinion letters which were crucial to distribution of the unregistered securities is sufficient to find him an aider and abettor of the scheme in deciding the motion for a preliminary imjunction. . . . His statements go beyond being mere mistakes in legal judgment to constitute probable violations of the anti-fraud provisions of the securities laws. ${ }^{134}$

In attempting to gauge the reasonablness of an investigation into a legal matter, the logical starting place is a study of the character of the misconstrued authority giving rise to the erroneous judgment. On this point the same sort of misconduct was imvolved in Lucas v. Hamm and Century Investment Transfer, since attorneys in botll cases misconstrued statutes. In the California case the statute was the highly complex Rule Against Perpetuities, and in the Century Investment Transfer case the statute was a straightforward provision of the 1933 Act that made the necessity for registration clear. The grey area between these poles is plainly a wide one.

Counsel may expect that every opinion dealing with matters of legal interpretation carries an implied representation of reasonable

132. 255 N.Y. at 189,174 N.E. at 448 .

133. [1971-1972 Transfer Binder] CCH FEd. SEC. L. REP. If 93,232 at 91,437

(S.D.N.Y. 1971).

134. Id. at 91,443 . 
professional care and skill. Where what might be expected to be a normal investigation has been limited by design or necessity, this qualification should be pointed out. Similarly, where counsel advocates a view that runs counter to existing authority on point, including administrative rulings, prudence would seen to require that the authority be noted and distinguished. Further, unless counsel can feel completely confident that his opinion will not be relied on-and that he can attract a Spectrum-style sympathy vote if it is-he should make clear and concise note of all qualifications directly in the text of the opinion itself, not just in the cover letter.

(4) The lawyer as a participant in the transaction. In the fall of 1971 SEC Commissioner Philip A. Loomis, Jr. cautioned that the SEC liad concluded that when attorneys go beyond their traditional role as private counselors to hold themselves out in a way that encourages investor reliance, they assume public responsibilities under the securities laws that might not otherwise apply:

We are concerned and inclined to feel that counsel who participate in action by a corporation have some public responsibility to investors and stockholders and not solely to corporate management. ${ }^{185}$

One familiar example of such participation is the use of opinions in the sale of unregistered stock, as in Spectrum and Century Investment Transfer. In this type of situation the lawyer's opinion takes on the characteristics of an affirmative representation like the certificate of title in Ward. What is needed to establisli participation in a transaction violating the securities laws is some sort of reasonable nexus between the attorney's conduct and the harm complained of. While an opinion letter may satisfy the nexus requireinent, mere consultation with a client will not, unless, of course, the consultation is directed toward furtherance of a fraudulent scheme.

Wessel v. Buhler ${ }^{136}$ is an example of a court's refusal to allow recovery in a suit where there was no nexus between the defendant's professional conduct and the wrong for which the plamtiffs sought redress. In the Wessel case the Ninth Circuit refused to find an accountant liable under rule 10b-5 either directly or as an aider and abettor where his only activity was the preparation of financial stateinents for inanagement. The financials were not prepared for the use of plaintiffs, and there was no evidence that the plamtiffs even knew of the statements until after the suit was brought. Under these

135. N.Y.L.J., Nov. 8, 1972, at 1, col. 4.

136. 437 F.2d 279 (9th Cir. 1971). 
circumstances, the court was unwilling to hold that the accountant owed any independent duty to disclose the sorry state of his client's fimancial affairs to prospective investors:

We find nothing in Rule 10b-5 that purports to impose liability on anyone whose conduct consists solely of inaction. ... On the contrary, the exposure of independent accountants and others to such vistas of liability, limited only by the ingenuity of investors and their counsel, would lead to serious mischief. ${ }^{137}$

A seemingly extreme example of participation is presented in the 1971 Oregon district court decision of Black \& Co. v. NovaTech, Inc. ${ }^{138}$ In Black, the issue before the court was whether it could assert long-arm jurisdiction over California lawyers alleged to have participated in the sale of unregistered securities in Oregon in violation of Oregon blue sky laws, section 10(b), and rule 10b-5. The court held that the facts established sufficient participation by the firm and one of its lawyers named individually to vest it with long-arm jurisdiction. For Oregon blue sky purposes, the individual lawyer was held to have participated in the allegedly illegal distribution merely because "without his assistance [in preparing legal documents], the sale would not have been accomplished."139 The court said that this result would obtain "[e]ven if [the lawyer] did not know and could not have known of Nova-Tech's failure to register the securities . . ." 140 A similarly expansive view of participation was taken with regard to the law firm itself. Designation of the firm as the issuer's corporate counsel in its annual reports was held sufficient to make the firm's partners participants for process purposes with respect to the blue sky claim in any unlawful securities transaction in which the annual reports were used.

Lawyers familiar with "doing business" problems know that there is a vast difference between what constitutes doing business for purpose of service of process or venue as opposed to doing business in the substantive "qualification" sense. ${ }^{141}$ This dichotomy obviously applies in cases involving participation for purposes of exposure under the securities laws, as demonstrated by the ruling in

137. Id. at 283. The Wessel case is discussed in Ruder, supra note 119 at $642-44$. Professor Ruder points out that the "duty to warn" aspect of the holding can be better rationalized in terms of breach of a direct duty to disclose rather than in terms of secondary aider and abettor liability.

138. 333 F. Supp. 468 (D. Ore. 1971).

139. Id. at 472 .

140. Id.

141. E.g., 17 W. Fletcher, Cyclopedia of the LaW of Private CorporaTHONS $\$ 8465$ (1960). 
Black. Simply put, the flimsy types of nexus demanded by the court in Black to establish participation for jurisdictional purposes make no sense from the standpoint of gauging participation for purposes of substantive liability. The disclosure philospliy of the securities laws is designed to insure that "what you see is what you get;" if there has been no misplaced reliance, there should be no civil recovery in damage suits absent proof that the lawyer knowingly assisted others in perpetrating a fraud.

Taken together, the cases indicate that where counsel authors opimons in the securities area with the object of promoting action by others, he may expect to be lield accountable for misconduct sufficiently heedless to permit an inference of fraud. The Ninth Circuit in Wessel held that proof of some type of direct commumication between the attorney and the claimants would be necessary before the accountant's actions could be assailed under either direct liability or aider and abettor theories. Spectrum, lowever, gives evidence that proof of reliance by imvestors is not essential for aider and abettor liability in an SEC injunction action. The court in Spectrum, although well aware that the public had not rehed on the defendant attorney's opinion, excused him from liability not on the basis of nonreliance, but because there was no evidence of the defendant's knowledge of fraud. In sum, though Wessel indicates liability to third parties in damage suits will hinge in part on proof of reliance, Spectrum iniplicitly recognizes that counsel have an obligation to perform a "gatekeeper" function, and that conduct more culpable than siniple negligence will vest the SEC with a cause of action regardless of whether investors directly rely on the attorney in the transaction in question, and irrespective of whether the defendant attorney functions only as an attorney (as did the lawyers in Spectruin and the defendant attorney im Century Investment Transfer). The lawyer may say nothing, but the talking done by the opinion letter will be heard by the courts. ${ }^{142}$

Once participation in a transaction by rendition of an opinion letter takes place, facts may be discovered that cast doubt on the validity of conclusions reached in the opinion. In assessing counsel's responsibility for subsequently discovered facts, we again look to

142. For additional authority supporting this basic theme, see United States v. Benjamin, 328 F.2d 854 (2d Cir.), cert. denied, 377 U.S. 953 (1964) (discussed at text accompanying notes 191-92 infra); cf. United States v. Sarantos, 445 F.2d 877 (2d Cir. 1972) (discussed at text accompanying notes 188-90 infra); SEC v. Frank, 388 F.2d 486 (2d Cir. 1968) (discussed at note 112 supra). See also Comment, supra note 5, at 1012-16. 
the experience of the accounting profession for assistance. It will be recalled that in Wessel the court was unwilling to find that the defendant accountant had a duty to "blow the whistle" on his client absent some sort of pre-existing relationship between the accountant and plaintiffs. Fischer $v$. Klet $z^{143}$ provides us with a case where there was such a pre-existing relationship. In Fischer, the district court refused to dismiss claims asserted against Peat, Marwick, Mitchell \& Co. which arose out of the firm's certification of financials appearing in Yale Express System, Inc.'s 1963 annual report. The plaintiffs alleged that although the defendant accounting firm became aware sometime before the end of 1964 that the certified financials were materially misleading, it failed to make this information public until May of 1965 . The court held that the plaintiffs had stated causes of action under common law deceit theory as well as under section $10(\mathrm{~b})$ and rule $10 \mathrm{~b}-5$. In so holding, the court observed that " $[t]$ he common law has long required that a person who has made a representation must correct that representation if it becomes false and if he knows people are relying on it."144 The lesson of the Fischer case as to the duty of an accountant to disclose subsequently discovered information of a material nature exisiting at the date of his report has since been embodied in a Statement. on Auditing Procedure promulgated by the American Institute of Certified Public Accountants. ${ }^{145}$ As was the case in the area of professionals' reliance on opinions prepared by others, there seems to be no reason why a court should require less of lawyers who participate in a transaction by rendering opinions than it would deinand of accountants whose audit certificates are rehed upon. ${ }^{146}$

143. 266 F. Supp. 180 (S.D.N.Y. 1967).

144. Id. at 188. The court also refused to dismiss the plaintiff's claim that the defendants had violated section 18(a) of the 1934 Act, 15 U.S.C. $\& 78 \mathrm{r}$ (1970), by permitting the company to file with the SEC a $10-\mathrm{K}$ report containing financial statements known by the defendants to be false and misleading. Id. at 189.

145. Comm, on Auditing Procedure, American Institute of Certified Public Accountants, Statement on Auditing Procedure No. 41, Subsequent DisCovery of Facts Existing At the Date of the Audrtor's Report (1969). Cf. american Institute of Certified Public Accountants, Code of Professional ETHICS AND INTERPRETATTVE OPINIONS 16-17 (1971). Interpretative Opinion No. 8 provides in part:

In a circumstance where a member believes the financial statements are false or misleading as a whole or in any significant respect, it is the opinion of the committee that he should require adjustments of the accounts or adequate disclosure of the facts, as the case may be, and failing this the independent accountant should refuse to permit his name to be associated with the statements in any way. Id. at 17 .

146. See TransCrIPT, supra note 14, at 243-44 (stating that the question is not whether an accountant or a lawyer has a duty to disclose subsequently discovered 


\section{THE National Student Marketing CASE}

The significance of the SEC's complaint in the National Student Marketing action transcends the allegations and theories of relief there asserted to touch the very essence of the American legal profession at this point in history. One legal historian has pointed out that about a century ago it was the opinion letter that served as the vehicle which brought lawyers into increasingly closer contact with their business clients, as businessmen began to seek the judgments of the leading advocates of the day. ${ }^{147}$ Today we see the opinion letter again serving as the catalyst for change.

In this portion of the article the significance of the SEC's charges is explored from several perspectives. First, we shall examine some of the forces at work within the legal profession that help to explain why the SEC's action was taken at this juncture. Following that inquiry, a brief analysis of recent developments under the securities laws relating to the exposure of professionals for fraud and malpractice serves to introduce an examination of the opinion letter claims asserted by the SEC. These discussions in turn set the stage for a synthesis set forth in the next section of the article in the form of a "model code" of policies and procedures for use in preparing legal opimions.

\section{Ideas in the Air}

In his latest work, that well known stock market seer "Adam Smith" takes time to remind us that

[w] ignore revolutions at our peril. Current evidences may or may not lead to profound changes, but we know that even when changes seem to happen quickly, the ideas behind them have been hanging in the air for a long time. ${ }^{148}$

pre-existing facts, but how soon after discovery must he comply with that duty). On this latter point Mr. Abraham Pomerantz took the view that prompt disclosure was required:

[T]he point is that the moment you are put on notice that your statement may be false, it's your duty to hurry up and get your night shifts working to get at the facts and then promptly, without fooling around, say to the public, "We are sorry, but this statement was maccurate, through no fault of ours. Our client did not tell us the truth or such an item showed up or it was an innocent error," what have you. I don't care about semantics. What's important is when you say the earnings are $\$ 11.12$ a share and it tums out they are zero a share, I thimk it's shocking to sit quiet, sit on your hands, and permit your good name ... to act as a perpetual representation, and by hypothesis, a perpetual rigging of the market, because it is market manipulation to permit false statements to circulate over your signature. My God! Id. at $244-45$.

147. J. HURST, The Growth of AMERICAN LAW 303 (1950).

148. SUPERMONEY, supra note 110 , at 282. 
So it goes for an attorney's responsibilities under the securities laws vis-à-vis his corporate client, the SEC and the investing public.

At the outset of this article it was noted that the development of the symbiotic relationship between the legal profession and its corporate clients did not draw rave reviews in all quarters. ${ }^{149}$ At the core of the critics' arguments was the fear that the legal profession risked diminishing its stature and independence of thouglit and action by rushing pell-mell to satisfy the great demands of its corporate clients. The SEC's complaint in the National Student Marketing case gives us reason to reflect anew on these venerable insights.

At another point im the introductory section of this paper, it was noted that these are times of expanding constituencies generally, with more stringent standards of conduct coming to the fore. ${ }^{150}$ In an age when the chief executive officer of the world's largest corporation feels compelled to make a public apology to a private citizen, ${ }^{151}$ it is only natural that members of a profession historically vested with a public trust be held to a standard of accountability that accurately reflects the tenor of the times. California's Supreme Court has already recoguized this trutl1; ${ }^{152}$ other courts can be expected to follow. But while there is some of this "new morality" at work in the SEC's complaint, it is by no means the primary ingredient.

The influence that can be viewed as the essential ingredient in the SEC's complaint has less to do with abstract generalizations about public responsibility than with the hard realities of what makes the stock market work. Again, we have insight from "Adam Smith," that "the market does not follow logic, it follows some mysterious tides of mass psychology." 153 And as Mr. Smith informs us, the key component determining the direction and substance of that mass psychology is the belief on the part of an investor that he is getting a fair value for his investment dollar:

[T] he actions of all investors, individual and institutional, professional and nonprofessional, have to be based on the belief that leadership knows what it is doing and that rational men are handling the nation's bnsiness rationally. If that belief fades, then so do the narkets. They do not merely dive, they dive and they disappear. It

149. See notes 7-10 supra and accompanying text.

150. See notes 17-18 supra and accompanying text.

151. One journalist's view of the facts surrounding this incident is set forth in T. Whiteside, The Investigation of Ralph Nader (1972).

152. See notes 58 \& 61 supra and accompanying text.

153. "Adam SMTth," The Money Game 236-37 (1968). 
happened here in the blight of the spirit from 1930 to 1933 , and it has happened in other countries.

Can it all come tumbling down? In a paper market, based on belief, this fear is universal, no matter how deep it is buried. Sure, it can all come tumbling down. All it takes is for behief to go away. ${ }^{154}$

Seen against the backdrop of such debacles as Continental Vending, Westec and Penn Central, ${ }^{155}$ the SEC's National Student Marketing complaint appears as an effort to bolster confidence in the securities markets by impressimg corporate managements and their advisors with the magnitude of their responsibilities nnder the securities laws and with the potential for personal and professional humiliation as a penalty for failure to discharge those responsibilities. ${ }^{156}$

In line with this need to foster investor confidence in the imtegrity of the securities inarkets is the movement by the SEC in its $\mathrm{Na}$ tional Student Marketing charges to bring about a state of parity between the professions in terms of their public responsibilities. The inevitability of this development las been apparent for some time. The reported reaction to the 1968 decision of Escott v. BarChris Construction Corp. ${ }^{157}$ reveals the extent to which lawyers and accountants had become accustomed to thinking in terms of their public responsibilities:

154. Id. at 283-84. As proof of his thesis, Mr. Smith relates a conversation he had with his friend Charlie, "a master gunslinger running a very aggressive fund," on a day stock prices plunged:

Charlie and I drift back to his office. "It's a terrible market for everybody but me," Charlie says. "Nobody believes anything. They don't believe Johnson, they don't believe anything in Washington, they believe taxes are going to go up but not enough, they don't believe we will ever get out of Vietnam, and after Motorola, nobody will believe any earnings. Let Peat Marwick the CPA's certify them, they still won't believe them." Id. at 242 .

As noted by Mr. Smith, the Depression stands as stark testimony to the tendency of irrational behavior on the part of businessmen to prompt financial ruin and undermine investor confidence in the fair and effective functioning of the securities markets. But common sense warns that investor confidence does not die only when it is crushed in a massive depression, for belief can be bled dry slowly, with the collapse of one company after another eventually taking its toll.

155. For insights into these instances of managerial malfeasance, see respectively, United States v. Simon, 425 F.2d 796 (2d Cir. 1969), cert. denied, 397 U.S. 1006 (1970); Wall Street J., Oct. 3, 1972, at 1, col. 6; Letter of Transmittal, SEC Staff Study of the Financial Collapse of the Peun Central Co., CCH FED. SEC. L. REP. If 78,931 (1972). These and other fiascos are illumined in A. BrILOFF, UNACCOUNTABLE ACCOUNTING (1972).

156. The need for protecting the public's belief in the fairness of the securities markets was a theme often stressed by former SEC Chairman William J. Casey. E.g., Casey, The SEC's Strategy for Increasing Investor Confidence in the Integrity of Our Capital Markets, 28 Bus. LaW. 537 (1973).

157. 283 F. Supp. 643 (S.D.N.Y. 1968). 
What upsets the financial community is that some of the defendants-found careless by the judge-did as much checking as many of their colleagues do in similar situations . . . .

"We'd get fired if we asked to see the backlog contracts," says one Wall Street lawyer.

"This decision will give any lawyer the willies," says another Wall Streeter. "You have to say, 'Oh, we've been doing this all along,' But the fact is we haven't."

An accountant says this interpretation of due diligence is harsh. But he adds: "We've been burnt in court before. It's the lawyers and underwriters who aren't used to the law looking over their shoulder like this." 158

The handwringing with which the legal profession greeted BarChris was in large part attributable to recognition by attorneys that standards of diligence throughout the securities bar generally had slipped. ${ }^{159}$ Still, there was sone cause for relief in Judge McLean's ruling that it was the defendant accountants, not the lawyer who prepared the registration statement, who were considered to be "experts" under section 11 of the 1933 Act. ${ }^{180}$ Thus, the "thein and us" attitude survived intact. Froin the omniscience of hindsight we can see that too few lawyers looked beyond the specific terms of the BarChris case to the threat of exposure to liability under the securities laws for their opinion letters. Those who did assess the implications of BarChris know that there was more than a grain of truth in the view that

[a] lot of lawyers can take lessons from accountants. The accounting profession has been justifiably frightened by some law suits against auditors of the highest caliber, with the result that they are more visibly articulating positions. ${ }^{161}$

The truth of this comment is evidenced by the existence of the recent Statements on Auditing Procedure, ${ }^{162}$ relied upon in preceding sections of this article, which cover topics sucl as the use of other auditors' opinions and subsequent discovery of facts affecting the validity of an audit certificate. ${ }^{163}$

158. Wall Street J., May 14, 1968, at 1, col. 6 .

159. BarChris Institute, supra note 67 , at $550 \& 554,561,621$ (remarks of F. Arnold Daum, Ralph H. Demmler and Kenneth J. Bialkin, respectively).

160. The concept of a lawyer acting as an expert under section 11 was discussed earlier in connection with the analysis of accountants' letters and opinion rendered in the course of work on public offerings. See notes 74-83 supra and accompanying text.

161. PLI, Protecting the Corporate Officer and Director From Liability 28 (1970) (remarks of Alan Appelbaum).

162. For example see notes 129, 145 supra and accompanying text.

163. Remarks attributed to an "SEC official" in a recent study of changing re- 
Implicit in the idea of the National Student Marketing complaint as representing a sort of SEC "crackdown" on the legal profession is the proposition that the profession has failed to discharge adequately its vital task of self-regulation. Reliable evidence suggests that this is the case. In 1969 the American Bar Association's Special Committee on Evaluation of Disciplinary Enforcement commenced its report on the results of its three-year study of professional discipline by saying that it had discovered "a scandalous situation that requires the immediate attention of the profession."164 The report went on to note that lawyers' views toward disciplinary enforcement ranged "from apathy to outright hostility."165 Another recent study by the American Bar Foundation was synthesized in a report that imcluded the finding of "too little evidence of professional as opposed to trade performance by the individual lawyer and no evidence of serious professional self-regulation toward diverting the profession to the pursuit of the common good-the public interest."106

One example of the fruits of this legacy of inadequate self-regulation by the legal profession is the current state of uncertainty among securities lawyers as to counsel's responsibility regarding public disclosure of a potential material adverse development, the occurrence of which is contingent on some other event (such as suit before the running of the statute of limitations). Does counsel have an obligation to risk turning such a contingent liability into an actual one by disclosing the as yet undiscovered discrepancy in periodic reports filed with the $\mathrm{SEC}^{\mathbf{1 6 7}}$ that would be open to inspection by the public? To answer the question requires that a lawyer review several different levels of competing policy considerations, for the dilemma of whether counsel must risk turning a contingent hability

sponsibilities of securities counsel likewise recognize that lawyers have lagged behind accountants in articulating standards of professional conduct. The official is said to have remarked that, compared to the legal profession, "the accounting profession has been much more solicitous of SEC opinion concerning professional standards." See The Changing Responsibilities of Securities Counsel, BNA SEC. REg. \&. L. REP. No. 109, at B-5 (1971). The official is also reported to have asked, "[W]hy isn't the American Bar Association ever down here to discuss problems that attorneys have?" Id.

164. ABA Special Comm. on Evaluation of Disciplinary Enforcement, Problems and Recommendations in Disciplinary ENForCement 1 (1969).

165. Id.

166. F. Marks, K. Leswing \& B. Fortinski, The Lawyer, The Public and PROFESSIONAL RESPONSIBIIITY 288 (1972).

167. The reports might include Form 8-K and Form 10-K, 17 C.F.R. \$§ $249.308, .310$ (1972). Form 8-K is used for current reports required by rule 13a-11 or rule $15 \mathrm{~d}-11$, id. $\$ \S 240.13 \mathrm{a}-11, .15 \mathrm{~d}-11$. Form $10-\mathrm{K}$ is used for annual reports required under sections 13 or 15 (d) of the Securities Exchange Act of 1934, 15 U.S.C. $\S \S 78 \mathrm{~m}, 780$ (d) (1970). 
into an actual one involves a choice on several different levels between obligations owed by lawyers. At one level there is the need to pick between the lawyer's duty to look after his client's ${ }^{168}$ financial welfare which will suffer if the contingent liability becomes an actual one because of disclosure, and his duty of fairness and candor to the SEC. At another level there is the choice to be made between the financial interests of current shareholders, whose equity stake may be depleted if disclosure is made, and investors who might defer a decision to buy the company's stock if the true state of affairs were known. On yet another level there is the need for the lawyer to decide between the wishes and self-interest of management, perhaps his close personal friends, and the abstract public responsibility lawyers owe because of their professional status. Respected commentators lave taken opposing views as to the proper answer to this type of hypothetical. ${ }^{169}$

We have already seen evidence of a growing trend toward increased recognition of the public trust inherent in the lawyer's status as a professional. One example is the California Supreme Court's

168. As pointed out in note 16 supra, according to the Code of Professional Responsibility a corporate lawyer's "client" is "the entity and not ... a stockholder, director, officer, employee, representative, or other person connected with the entity."

169. At a recent Practising Law Institute gathering, the participants discussed the question of whether counsel should disclose such a contingent liability. The Practising Law Institute's Fourth Annual Institute on Securities Regulation was held in New York City on Nov. 2-4, 1972. In the problem posed, no prior opinion by counsel was affected by the problem. (It was conceded that Fischer $v$. Kletz would govern where the discovery affected a previously issued opinion on which reliance could still be placed). In addressing the contingent liability hypothetical, former SECC Commissioner Francis M. Wheat indicated that an attorney has no duty to "blow the whistle" on his client by disclosing the problem in a report filed with the SEC. Not surprisingly, exactly the opposite position was taken by another member of the PLI panel, Irving M. Pollack, Director of the SEC's Division of Enforcement. Surely there can be no question of the eminence or good faith of either Mr. Wheat or Mr. Pollack. Just as surely, the issue involved is a vastly important one, reaching to the heart of the corporate lawyer's responsibilities to management, shareholders, the corporate entity, the SEC and the imvesting public. And the hypothetical can ultimately have only one correct answer. Some indication of the thoughts of Congress on the matter may be found in sections 18 and 32 of the 1934 Act, 15 U.S.C. $\$ \$ 78 \mathrm{r}$, ff (1970). Those sections provide in turn for civil and crininal liability on the part of any person who knowingly makes or causes to be made any statement in a report filed under the law that is "false or misleading with respect to any material fact." Case law also casts doubt on the propriety of counsel's advising his client to file a false report. See United States v. Sarantos, 455 F.2d 877, 881 (2d Cir. 1972), where the Second Circuit stated: "We have lield and continue to hold that [an attorney] cannot counsel others to make statements in the face of obvious indications of which he is aware that those assertions are not true." 
declaration that the lawyer's "responsibility must broaden and deepen" as more individuals find it increasingly necessary to rely upon his expertise. ${ }^{170}$ Unfortunately, connecting the dots that inark this inevitable trend are judicial decisions involving fractured professional careers. The National Student Marketing drama should teach the bar that litigation is a distasteful and unnecessary way to go about the job of professional developinent. If it does, and if the formulation of workable guidelines to govern the conduct of corporate counsel results, then our hypothetical need not be answered in the courts.

Viewed in the light of the American Bar Association and American Bar Federation commentaries and the uncertainty over the right answer to the contingent liability hypothetical, the SEC's decision to become the legal profession's policeman is understandable. Even inore than being understandable, the Commission's new role as policeman is symbolic of the truism that the times have changed, for it was just slightly over twenty years ago that the Commission itself was drawing intense criticism for its seeming failure to probe diligently the circuinstances surrounding the filing of a registration stateinent found to be inaterially misleading by the Second Circuit in Kaiser-Frazer Corp. v. Otis \& Co. ${ }^{171}$ In National Student Marketing

170. See note 21 supra.

171. 195 F.2d 838 (2d Cir.), cert. denied, 344 U.S. 856 (1952). The misstatement in the registration statement that was isolated by the Second Circuit had to do with the inflation of the issuer's eamings in financials accompanying the registration statement. The earnings for December of 1947 (the most recent month for which figures were available at the effective date) were stated to be 4 million dollars. In truth, the figure was $\$ 900,000$, with the difference being made up of adjustments that should have been prorated over the entire year. The SEC's handling of the Kaiser-Frazer registration statement controversy is discussed in a report prepared by a special Securities and Exchange Subcommittee created by the House Committee on Interstate and Foreign Commerce. H.R. REP. No. 2508, 82d Cong., 2d Sess. (1952). Among other things, the report mentions testimony by SEC chairman Donald $\mathrm{C}$. Cook to the effect that the issuer, underwriters and the accountants "knew the facts" relating to the misleading nature of the December figures prior to the filing of the registration statement. Id. at 56.

In the summary of its discussion of the handling of the Kaiser-Frazer situation by the Commission, the investigating subcommittee stated that the Commission's handling of the affair

reveals a shocking story of errors, indifference, and evasion on the part of the Commission and its staff. We are satisfied from the investigation we have made thus far of the case that from the very beginning the commission and its staff members were either "asleep at the svitch" or deliberately ignored the facts that were available to them. Id. at 91 .

What may perhaps have contributed to the lethargy on the part of the SEC that was scored in the report was the identity of one of the issuer's accountantsWilliam W. Werntz. Less than two years before the registration statement was filed, Mr. Werntz had been on the Commission's payroll as its chief accountant. If this factor caused the Commission to "go easy" on the principals in the Kaiser-Frazer case, there is eveny indication that the same treatment would not be 
the Commission is again embroiled in controversy-this time because it has allegedly gone too far, rather than not far enough.

\section{The Allegations}

The SEC's complaint in the National Student Marketing action alleges liability on the part of the defendant attorneys under the securities laws arising from claimed malfeasance in three different opinion letter settings: (1) rendering opinion letters as a condition precedent to the closing of a business transaction; (2) giving a legal opinion stating in substance that certain securities may be sold; and (3) rendering opinions as to the legal effect of a business transaction for use by independent accountants in the certification of financial statements disseminated to stockholders and the investing public. For convenience, these different opinion letter situations will be respectively referred to as the "Inerger opinions," the "stock sale opinion" and the "Compujob opinions." An analysis of the various theories for relief asserted by the SEC follows individual consideration of the SEC's allegations.

The merger opinions. The second count of the Commission's complaint alleges in substance that defendants White \& Case and Lord, Bissell \& Brook and certain of their lawyers violated the securities laws ${ }^{172}$ by fraudulently issuing opinions in connection with consummation of a merger between National Student Marketing Corporation (NSMC) and Interstate National Corporation (INC). The Commission's allegations stem from representations made in a proposed merger agreement distributed to INC and NSMC shareholders in connection with a proxy solicitation relative to the planned merger. For present purposes, the significant representations in the proxy materials were that (1) NSMC's earnings for the nine-inonth period ended May 31, 1969 were $\$ 700,000$, and (2) consummation of the merger was contingent upon (a) Peat, Marwick, Mitchell \& Co.'s (PMM) issuance of a comfort letter stating, inter alia, that NSMC's nine-month interim financial statements were not materially mislead-

forthcoming today. See SEC v. Vesco, 72 Civ. 5001 (S.D.N.Y., filed Nov. 27, 1972), in which antifraud charges are leveled at Alan F. Conwill, a New York City lawyer, who served as General Counsel and later as Director of the SEC's Division of Corporate Regulation from 1961-64. It deserves mention that even the SEC's action in Vesco has been the subject of criticism. See Wall Street J., May 14, 1973, at 1 , col. 1 .

172. White \& Case and one of its partners were charged with violating section 17(a) of the 1933 Act, 15 U.S.C. $\$ 77 q(a)$ (1970), and sections $10(b), 13(a)$ and $14(\mathrm{a})$ of the Securities Exchange Act of 1934 , id. $\$ \$ 78 \mathrm{j}(\mathrm{b}), 78 \mathrm{~m}(\mathrm{a}), 78 \mathrm{n}(\mathrm{a})$, and various rules promulgated thereunder, including rule 10b-5, 17 C.F.R. $\$ 240.10 \mathrm{~b}-5$ (1972). Lord, Bissell and two of its partners were charged under section 17(a) of the 1933 Act, section 10(b) of the 1934 Act and rule 10b-5 thereunder. 
ing, and (b) the issuance of opinion letters by White \& Case and Lord, Bissell stating that all steps taken to consummate the merger had been vahdly taken and that, to the knowledge of counsel, their respective clients had complied with the law.

According to the SEC's allegations, in the course of reviewing NSMC's financials PMM determined that the $\$ 700,000$ figure reported in the proxy materials mailed to shareholders was not arrived at by application of generally accepted accounting principles. Rather, as revealed by PMM's investigation, NSMC actually had sustained a net loss for that period. These facts in turn caused the comfort letter to fail to satisfy the role assigned it in the proxy materials. Notwithstanding this complication, and despite the dark shadow that PMM's judgment cast over the validity of the proxy solicitation materials in which the $\$ 700,000$ earnings representation appeared, ${ }^{173}$ the defendant attorneys issued their opinion letters stating that all steps necessary to effectuate the merger had been taken and that, to their knowledge, no violation of law had occurred.

These factual allegations, which are obviously serious enough in themselves, do not disclose the complete contour of the merger opinion case the SEC intends to make against defendant attorneys. The allegation that has caused the lion's share of the notoriety already garnered by the Commission's action urges that the attorneys be held liable not only for their issuance of misleading opinions but also for their failure to take strenuous affirmative action to remedy the effects of the allegedly improper proxy solicitation, including the exertion of pressure on their clients:

As part of the fraudulent scheme White \& Case, Epley, Lord Bissell \& Brook, Meyer and Schauer failed to refuse to issue their opinions . . . and failed to insist that the fimancial statements be re-

173. Proxy rule 14a-9 provides in part:

No solicitation ... shall be made by means of any proxy statement ... containing any statement which, at the time and in light of the circumstances under which it is made, is false or misleading with respect to any material fact .... 17 C.F.R. \& $240.14 a-9$ (1972).

The concept of shareholder rule through the device of proxy machinery is fundamental to our corporate system. As was stated by a former SEC Commissioner,

[l]egally, and in fact, the stockholders of a corporation are its owners. As such they should have the ultimate voice in choosing their representatives in the corporate management and in determining crucial corporate issues such as mergers, consolidations, liquidations and so forth. Whether or not the owners of the enterprise have an effective voice in running it depends on the means afforded to them for exercising the right to vote. Address by Edward T. McCormick, East Side Forum on Public Affairs, Feb. 13, 1951, reported in Hearings on Powers, Duties and Functions of the Securities and Exchange Commission Before a Subcomm. of the House Comm. on Interstate and Foreign Commerce, 82d Cong., 2d Sess., at 112 (1952). 
vised and shareholders be resolicited, and failing that, to cease representing their respective clients and, under the circumstances, notify the plaintiff Commission concerning the misleading nature of the nine-month financial statement. ${ }^{174}$

The stock sale opinion. The SEC's second opinion letter claim alleges the issuance of an opinion by defendant Lord, Bissell, INC's counsel, after PMM's comfort letter disclosure of the inaccurate nature of NSMC's interim financials. The opinion was issued at the request of White \& Case, NSMC's counsel, and stated in substance that certain NSMC shares acquired by certain INC shareholders pursuant to the merger could be sold. The opinion made no mention of the need for adjustments in the interim financials, or of the need for public disclosure of the comfort letter before the shares could be lawfully sold, so that persons purchasing the stock could be aware of the true state of NSMC's finances.

The Compujob opinions. The SEC's third opinion letter claim charges in part that Robert A. Katz, a New York attorney, issued materially false and misleading legal opinions related to the purchase by his clients of Coinpujob, Inc., a wholly-owned subsidiary of NSMC. White \& Case subsequently rendered an opinion which concurred with the conclusion reached by Katz. ${ }^{175}$. The SEC alleges that the lawyers knew or should have known that NSMC intended to use the opinions to satisfy PMM that the sale of Compujob and NSMC's gain therefrom could be accounted for in NSMC's financial statements for the fiscal year ended August 31, 1969. The SEC termed the opinions "false and misleading" because they failed to indicate that, ainong other things, negotiations for the sale of the subsidiary had not even commenced as of the August date.

\section{Analysis}

The Compujob opinions-achieving parity between the professions. In a book appropriately entitled The Funny Money Game, a former NSMC vice president comments on the decision to account for the sale of Compujob in NSMC's August 31 financial statements:

When NSMC's 1969 fiscal year ended (August 31) it was clear that the earnings projections, [NSMC's chief executive officer] had made would be impossible to meet without a little "creative accounting."

174. Complaint, supra note 1 , at $\int 48 \mathrm{i}$.

175. The Commission's last claim for relief also contains a separate opinion letter charge against White \& Case and one of its partners in cormection with NSMC's disposition of Collegiate Advertising, Ltd. The allegations involved in that charge are substantially identical to the Compujob claims and are not discussed individually here. 
He needed to show about three and one-half million dollars in net earnings. Two problems were Compujob, which you will recall lost a lot of money despite the good publicity it produced for NSMC and the Canadian arm of NSMC. So on November 30,90 days after the fiscal year had ended, an agreement was made to sell Compujob back to Tan and Ed and the Canadian operation to its managers. According to the footnote, "in the opinion of counsel in both transactions negotiations and agreements of sale were in effect consummated prior to August 31,1969 . . ." These transactions allowed NSMC to add $\$ 369,000$ in after-tax earnings, or about $10 \%$ to its 1969 results . . . .

How could something I saw everybody sweating over the night of November 29 have, in effect, been consummated prior to August 31 ? But I am not a lawyer or accountant, and our lawyers and accountants were evidently on record saying this was OK. ${ }^{178}$

This talk about "creative accounting" evokes the realization that abusive accounting practices, like the departures from the straight and narrow by corporate officers and directors that Chief Justice Stone referred to, "do not usually occur without the active assistance"177 of some nember of the legal profession. A case in point is United States v. Simon. ${ }^{178}$

The Simon case centered on actions taken by nembers of the leading international accounting firm of Lybrand, Ross Bros. \& Montgoinery in drawing up and certifying a false and misleading balance sheet of Continental Vending Machine Corp. as of September 30, 1962. The principal charge against the accountants was that they had failed to disclose that money supposedly being loaned to a subsidiary, Valley Corp., was simply being funneled through the subsidiary into the stock inarket for the private account of Harold Roth, who was chief executive officer and the controlling shareholder of Continental, and who also controlled the subsidiary. The indictment against the accountants further charged that they were remiss in failing to disclose in the balance sheet that the account receivable of Continental growing out of the loans to the subsidiary was inadequately secured. In fact, the loans were not adequately secured, and it is im connection with this development that a

176. A. Tobias, The FunNy Monex Game 135-36 (1971). Needless to say, the rosy pieture which was painted of NSMC's operations in the news media during this period gave the investing public little reason to suspect that "creative accounting" Inay have played a role in the company's success. E.g., Getting Across to the Young, Bus. WEEK, Oct. 18, 1969, at 89.

177. Stone, supra note 9 , at 9 .

178. 425 F.2d 796 (2d Cir. 1969), cert. denied, 397 U.S. 1006 (1970). 
lawyer assisted the Lybrand, Ross defendants in fashioning some "creative accounting."

The attorney in question was Arthur Field, Continental's general counsel and a long-time friend of Roth. Field was a onequarter owner of the Continental subsidiary in question, and he had served as a director of Continental until 1960 when his partner succeeded him. He had received Valley's financial statements and had known since 1957 that Roth borrowed from the subsidiary. ${ }^{179}$

When it became clear that the subsidiary could not pay the debt it had incurred on Roth's behalf, Roth offered to post his equity in certain securities and a mortgage on his home and furnishings to secure the debt owed by the subsidiary to Continental. Lybrand's partner in charge decided that if adequate collateral were posted, a satisfactory opinion froin Field obtained, and approval of the transaction given by Continental's board, there would be adequate evidence of the receivable's collectibility. In a letter sent on February 18, Field gave Lybrand, Ross his opinion that the loan of some $\$ 3.5$ million was "adequately secured."180 By February 25, the market value of the security was only $\$ 395,000$, and on that same day a Continental check to the Internal Revenue Service was returned for insufficient funds. A few days later, the government padlocked the plant and the American Stock Exchange suspended trading in Continental stock. Investigations by the SEC and bankruptcy rapidly ensued.

Comparison of the opinion letter circumstances involved in the Simon case with the alleged facts surrounding issuance of the Compujob opinion letters by Katz and White \& Case in the National Student Marketing complaint shows little difference in the contexts in which the opinion letters were rendered. The maim difference between the situation in Simon and the Coinpujob charge in the National Student Marketing complaint is, of course, that the "men of blameless hives and respected members of a learned profession"181 who had their professional careers ruined in the Simon case were all accountants; Field never stood trial. ${ }^{182}$ The sharp contrast between this situation and the fate that may be awaiting the defendant attorneys in the National Student Marketing case is itself stark testimony

179. Note, The Criminal Liability of Public Accountants: A Study of United States v. Simon, 46 Notre Dame Law. 564, 580-81 n.45 (1971).

180. 425 F.2d at 803 .

181. Id. at 799.

182. Eleven co-conspirators were originally named, but at the conclusion of the proceedings only Roth and the accountants remained implicated. Note, The Criminal Liability of Public Accountants, supra note 179, at 570. 
to the momentous nature of the SEC's campaign to remind the bar that lawyers "have a special responsibility in the securities area, just as accountants and other professionals do."183

The substantive basis for the potential liability of the defendant attorneys for their Compujob opinions centers on the concept of aider and abettor violations of the securities laws discussed earlier. ${ }^{184}$ The complaimt faults the attorneys for rendering bpinions whicl they "knew or should have known that defendant NSMC intended to use ... to satisfy PMM that sale of Compujob could be accounted for in defendant NSMC's fiscal year ended August 31, 1969."185 Thus, it is not the issuance of the opinions per se that the SEC charges was illegal; rather, the SEC is attackmg the issuance of the opinions with the purpose of giving NSMC assistance in its efforts to persuade PMM to include the effects of the Compujob transaction in the year-end totals. This allegation, if sustained, is the essence of actionable aiding and abetting under the securities laws.

As noted previously, an aider and abettor violation 'of the securities laws has three elements: first, there inust be an imdependent wrong; second, the alleged aider and abettor must have "knowledge" of the wrongful course of conduct; and third, he inust give some quantum of active assistance to the wrongdoing. ${ }^{186}$ In the context of the unproven allegations in the complaint, the first prerequisite is satisfied by the SEC's separate stock fraud charge agamst PMM based on certification of the August 31 financials. The second prerequisite is met by the SEC's charges that defendant attorneys "knew or should have known" that the opinions were materially false and misleading. At the very least, the SEC's factual charges make out a case for branding the attorney's conduct as reckless and, for aider and abettor purposes, "knowledge can be shown by reckless conduct or through inference." 187 The final prerequisite is satisfied by the allegations that the attorneys "knew or should have known" that

183. N.Y.L.J., Mar. 6, 1972, at 1, col. 3 (remark of former SEC Commissioner Needham).

184. See notes 122-24 supra and accompanying text. Also set forth in the SEC's first claim for relief are a potpourri of charges against PMM for fraudulent accounting practices, including a charge that essentially parallels the SEC Compujob allegations against defendant attorneys. Compare Complaint, supra note 1 , at II 39(i) with $i d$. at II 54,55 . If correct, those charges would result in direct liability for PMM under the securities laws for its fraudulent certification of NSMC's 1969 Annual Report.

185. Complaint, supra note 1, at \I 54.

186. See notes 122-24 supra and accompanying text.

187. Ruder, supra note 119, at 638 . 
NSMC would use the opinions to give PMM an excuse to certify the allegedly inflated year-end figures.

Strong support for the SEC's proposition that lawyers, acting as lawyers, may be held hable under the aider and abettor theory is found in United States $v$. Sarantos, ${ }^{188}$ a Second Circuit case decided on the same day the National Student Marketing complaint was filed. The defendant attorney in Sarantos, who had prepared a visa petition for an alien, was charged with thereby having aided and abetted an atteinpt by the alien to secure residency in the United States through a sham marriage. The attorney contended that he was entitled to take every representation from his chent at face value, and that to hold otherwise would "make the attorney 'an investigative arm of the government." "188 The court did not go so far as to hold that the attorney had an obligation to go beyond his chents' representations, but it did hold that counsel could not escape hability "merely by deliberately closing his eyes to the obvious risk that he is engaging in unlawful conduct," and that "he cannot counsel others to make statements in the face of obvious indications of which he is aware that those assertions are not true." 190

Significantly, the court in Sarantos buttressed its holding with citation to its earher ruling in United States v. Benjamin. ${ }^{191}$ The defendant attorney in Benjamin was held criminally liable for having knowingly rendered false opinion letters to facilitate the illegal sale of unregistered stock. It was in Benjamin that the Second Circuit placed lawyers' opinions and accountants' certificates on a par and affirmed that liability awaits the reckless:

In our complex society the accountant's certificate and the lawyer's opinion can be instruments for inflicting pecuniary loss more potent than the chisel or the crowbar. Of course, Congress did not mean that any mistake of law or misstatement of fact should subject an attorney or an accountant to criminal liability simply because more skillful practitioners would not have made thein. But Congress equally could not have intended that men holding themselves out as members of these ancient professions should be able to escape criminal liability on a plea of ignorance when they have shut their eyes to what was plainly to be seen or have represented a knowledge they knew they did not possess. ${ }^{192}$

188. 455 F.2d 877 (2d Cir. 1972).

189. Id. at 881 .

190. $1 d$.

191. 328 F.2d 854 (2d Cir.), cert. denied, 377 U.S. 953 (1964).

192. Id. at 863 . 
The potential utility of Sarantos and Benjamin has not been overlooked by the Commission. ${ }^{193}$

The stock sale opinion. The SEC's claim that Lord, Bissell issued its stock sale opinion on White \& Case's request "[i]n furtherance of a fraudulent scheme"194 likewise suggests aider-andabettor-style liability. The heart of the SEC's charge is, of course, that the firm issued a groundless opinion letter that had the effect of providing NSMC with an excuse for permitting the sale of its stock transferred pursuant to the NSMC-INC merger-a merger allegedly consummated with knowledge that the proxy solicitation had been defective.

As evidence of the baseless nature of the stock sale opinion, the SEC has alleged that Lord, Bissell neglected to consider both the true state of NSMC's interim financials and the contents of PMM's comfort letter. Apparently, the SEC has in mind its 1962 release taking the position that "[o]bviously, an attorney's opinion . . . is worthless ... if unspecified but vital facts are not considered."105 Having viewed the allegedly defective proxy solicitation as a sufficient basis for imstitution of this historic lawsuit against firms of the caliber of White \& Case, Lord, Bissell and PMM, it is not surprising that the Commission likewise views the implications of the comfort letter as something that should have been considered in connection with the rendition of an opinion freeing roughly $\$ 3$ million worth of stock for sale to an uninformed public pursuant to the merger.

This is not to say either that the complicating effect of the comfort letter was not in fact taken into account by Lord, Bissell and White \& Case concerning the stock sale opinion or that the facts revealed in the comfort letter were material to the transaction and not properly overridden by the "business decision" by INC's management to close the transaction notwithstanding the revelations con-

193. See Memorandum of the Securities and Exchange Commission in Opposition to the Motions of Defendants Lord, Bissell and Cameron Brown to Dismiss the Complaint for Failure to State a Claim Upon Which Relief can be Granted or, in the Alternative, for Summary Judgment and in Opposition to the Motion of Defendants Paul E. Allison, William J. Bach and Robert P. Tate for Summary Judgment at 29-30, SEC v. National Student Marketing Corp., Civ. Action No. 225-72 (D.D.C., filed Feb. 3, 1972); Memorandum of Points and Authorities of the Securities and Exchange Commission in Opposition to the Motions of Defendants White \& Case and Marion J. Epley, III to Dismiss, or Alternatively, to Sever and Transfer, at 9-10 \& n.12, id. The contested motions have been denied as to all movants except Allison, Bach and Tate. SEC v. National Student Marketing Corp., [1972-1973 Transfer Binder] CCH FED. SEC. L. REP. II 93,820, at 93,552 (D.D.C. 1973).

194. Complaint, supra note 1 , at $\Uparrow 50$.

195. SEC Securities Act Release No. 4445 (Feb. 2, 1962). 
cerning the questionable accuracy of the interim financials. With respect to the latter point, in the transaction in question INC appears to have had the right to waive any of the conditions to the merger, including PMM's rendition of a comfort letter in a form comporting with the requirements of the merger agreement. ${ }^{106}$ Further, INC's president is reported to have testified to the Commission that his concern at the closing was with NSMC's year-end earnings, and the restated interim figures apparently did not alter the anticipated year-end results. ${ }^{177}$

These additional revelations show that, like the contingent liability hypothetical, ${ }^{198}$ the SEC's National Student Marketing complaint involves the interpositioning of corporate counsel between the public interest in corporate democracy proinoted by shareholder votes cast after full and fair disclosure, and the duty of counsel to assist in executing difficult business decisions necessarily made on the spur of the moinent in the face of changing circuinstances. Compounding this conceptual dilemma is the prospect that counsel's judgment may be challenged regardless of the position taken. A demand on management that proxies be resolicited may destroy delicate timing and kill off a deal that might be in the long run best imterests of the shareholders. On the other hand, shareholders may well be expected to second-guess management and its advisors if performance does not measure up to expectations.

Gauging where the balance is to be struck in any given case is bound to be a difficult task for the business lawyer, but the need to choose is inescapable. It is surely true that what is or is not "material" is a kaleidoscopic inquiry, with slight twists in factual settings resulting in differences in outcome. Yet if the securities laws are to mean anything, boundaries must imevitably be drawn somewhere. In facing this important decision-1naking responsibility, a lawyer can take heart in the truism that courts recognize he is not an insurer of his opinions in the absence of an express agreement. Further, judges called upon to evaluate his reaction to the exigencies of practice may be 'expected to recall the Supreme Court's admomition in United States v. American Bell Telephone Co. ${ }^{198}$ regarding the use of hindsight in assessing conduct: "[A] wisdom born after the event is the cheapest of all wisdom."200

196. National Student Marketing, 5 REv. SEC. REg. 913, 914 (1972).

197. Id. at 914 n.1.

198. See notes 167-69 supra and accompanying text.

199. 167 U.S. 224 (1897).

200. Id. at 261 . 
Aside from the profound implications concerning the lawyer's multiple responsibilities inherent in the SEC's stock sale opinion claim, another aspect of the Commission's claim is of interest here. As noted, in the accounting profession the use of other auditors' opmions is permissible only if, at a minimum, the other auditors' professional reputation and independence have been established. ${ }^{201}$ Further, reliance on audits performed by outside auditors is permitted only where the reliant accountant can be satisfied with the audit's accuracy.

In charging securities laws violations by both the law firm that requested the stock sale opinion and the law firm that rendered it, the SEC apparently feels that White \& Case had sufficient notice of the alleged fraudulent scheme to understand that sale of the stock was improper regardless of the conclusion reached in Lord, Bissell's opinion. Apart from questions as to the propriety of reliance in the face of knowledge of the true situation, the wisdom of White \& Case's decision to scek the opinion from Lord, Bissell instead of counsel less interested in the transaction is also open to question. Along with White \& Case, Lord, Bissell was deeply involved in all aspects of the transaction giving rise to the stock sale which was the subject of the opinion. Additionally, one of Lord, Bissell's partmers served as director of INC, and this same director-partner allegedly prepared or directed the preparation of the stock sale opinion. Further, the Lord, Bissel director-partner allegedly sold some of his NSMC shares received pursuant to the merger at approxinnately the same time that shares were reportedly sold after issuance of the stock sale opinion.

This is not meant even to hint that Lord, Bissell's stock sale opinion does not represent the result of carefully exercised independent legal judgment, for the defendants have not yet had their day in court. However, one may wonder whether a law firn is wise to render an opinion, or expect another firm to render an opinion, in circumstances where the opining firm might have to rule "independently" on an important aspect of a transaction it has assisted in effectuating or where the opining lawyer wears a nunber of different hats, including one as an insider. Because of complications like these, some law firms have adopted the policy of restricting participation by their lawyers as investors in transactions in which the firm renders professional services. ${ }^{202}$

201. See text accompanying note 127-28 supra.

202. One reason for this policy was spelled out by a practitioner as follows: The fear really is, if you get sued in one of these cases in which 
On the aider and abettor issue, the SEC's case against the law firms is obviously not harmed by the Century Investment Transfer case, where the defendant attorney's opinions were looked on as crucial to the distribution of the unregistered securities and thus sufficient to find him an aider and abettor of the scheme in deciding the motion for a preliminary injunction. ${ }^{203}$ White \& Case's demand for an opinion on behalf of NSMC can arguably be viewed as making Lord, Bissell's opinion "crucial" to the transaction, and the SEC's factual allegations relative to the merger clearly call into question the propriety of the firm's alleged failure to confront the consequences of PMM's comfort letter.

The merger opinion. The SEC's allegations regarding the hability of defendant attorneys for the inerger opinions reveal a doublebarreled theory of recovery. First, the SEC asserts that the representations in the proxy solicitations that the opinions were to function as conditions made issuance of the opinions "crucial" to the merger and thus made the law firms participants in the transaction. Second, the SEC claims that "under the circumstances" the defendant attorneys had an obligation to notify the Commission as to the allegedly misleading nature of the interim financials failing all other efforts to rectify the adverse effects of the misleading proxy solicitation. These two facets of the SEC's merger opinions claim will be considered in order.

(1) Participation in the transaction. As with its stock sale claims, the SEC's merger opinion charges seem to depend on the view that since the lawyers allowed their opinions to becone "crucial" to the merger transaction as disclosed conditions precedent to consummation of the merger, the participation eleinent of anifraud liability was satisfied. Under the SEC's theory, the participatory nexus linking the attorneys' opinions to the merger is furnished by disclosure in the proxy material disseminated to shareholders. ${ }^{204}$

you were counsel for the company, and it turns out that a couple of your partners purchased substantial blocks of the stock, plaintiff may put you on the witness stand and say, "Did you purchase any? Did your partner?" . "Yes. He purchased 10,000 shares." "Was your vision colored because you hoped the offering would be successful?" Your answer is no; but the question was asked and the jury hears it, and as you all know from practicing, this may be all the difference in the world to the outcome of the case. Protecting the Corporate OFFicer, supra note 19, at 89-90 (remarks of Herbert S. Wander).

See also note 231 infra.

203. SEC v. Century Inv. Transfer Corp., [1971-1972 Transfer Binder] CCH FED. SEC. L. REP. \ 93,232, at 91,438 (S.D.N.Y. 1971).

204. One commentator has astutely synthesized the SEC's theory in one sentence:

When an attorney permits his naine to be used either in a registration statement or in any other document associated with a securities transac- 
The notion that attorneys will be attacked by the SEC in injunction actions if they appear to misperform obligations which they said in documents filed with the Commission they would undertake is not startling. The need for the Commission to be able to put its faith in the forthrightness and diligence of the securities bar is readily apparent, and it is recognized among the securities bar that the Commission does in fact depend on counsel. ${ }^{205}$ However, in this situation whether the same sort of participation in wrongdoing by the attorneys can be said to exist with respect to private litigants is open to soine doubt. On the one hand, there is some question whether investors actually rely on participation by law firms named in SEC documents, and the need for some sort of rehance is suggested by the Ninth Circuit's holding in Wessel v. Buhler. ${ }^{208}$ On the other hand, there is an adage that one is known by the company he keeps, and this proposition has not been lost on proprietors of unseasoned companies who endeavor to improve their companies' standing in the busmess community by surrounding themselves with well known and highly respected legal and accounting firms. Indeed, it has been commented that NSMC's management seems to have followed this approach to image enhancement. ${ }^{207}$ In cases where a reputable law firm has allowed itself to be held out to the investing public as providing counsel to an unseasoned company, there may perhaps exist an inference of reliance by the investing public on the firm that would not arise where the client's management had earned a

tion, and such attorney's opinion or other participation will have the effect of inducing third parties to rely upon that attorney's participation as to the validity of a transaction or the occurrence of an event, the attorney's responsibilities cease to be solely to his client and run to these third parties, of which the SEC may be one, if the attorney's representations are contained in a document filed with such agency. Goldberg, Attorney's Responsibilities to Third Parties: The National Student Marketing Case,

N.Y.L.J., March 10, 1972, at 1, col. 1.

205. Cf. Panel Discussion, supra note 20, at 960 (remarks of Robert H. Mundheim); PLI, Fourth ANNUAL INSTITUTE on Securuties Regulation 78 (1972) ("Noblesse oblige- the greater the reputation of the firm the more the Commission is likely to depend on it ... and thus the greater the potential responsibility and exposure.").

206. See notes 136-37 supra and accompanying text.

207. Speaking from hindsight, a former NSMC vice president has said that when he weighed his decision to join NSMC he felt that the company's story "was all a little unreal" but that this was not decisive because

soine awfully distinguished firms seemed to attest to NSMC's good character: Lawyers were White \& Case; auditors had been Arthur Andersen and were then (without even knowing the rest of the sentence, a Harvard Business School graduate would see red flags going up all over, but at the time I never thought to wonder why a company switched auditors) Peat, Marwick, Mitchell and Company (inore red flags, but $I$ had never lieard of Yale Express, and then who then knew what was going on at Penn Central?). A. TOBLAS, supra note 176, at 39. 
good reputation in the investment community through its own efforts.

(2) The duty to dissociate and disclose. The Commission's stance relative to defendant attorneys' merger opinions is that having become participants in the transaction by disclosure that their opinions were ingredients in the merger matrix, the defendant attorneys, upon divulgence of the misleading nature of the interim fimancial, had an obligation to demand the proxies be resolicited so the shareholders could rethink their votes on the merger in light of NSMC's true financial condition, or dissociate themselves from the transaction and, as a last resort, report the matter to the Commission. On the facts alleged (which, it bears reiteration, have not yet stood the test of adversary proceedings), the Commission's position seems to find support in case law and in the Code of Professional Responsibility.

As noted, in Fischer v. Kletz $z^{208}$ the plaintiff stated a good cause of action under common law and securities law theories where the defendant accountants were charged with failing to divulge promptly their discovery that financials they had earlier certified in good faith were in fact false and misleading. The subsequent embodiment by the accounting profession of the lesson of the Fischer case in a Statement of Auditing Procedure ${ }^{209}$ has also been pointed out. Additionally, an Interpretive Opimion to the accounting profession's Code of Professional Ethics demands that an accountant "should refuse to permit his naine to be associated ... in any way with financial statements known by him to be false or misleading as a whole or in any significant respect. . . ."210

A similar obligation to insure that professional conduct and reputation is untainted by association with wrongdoing is recognized by the legal profession. Disciplinary Rule 7-102(B) of the Code of Professional Responsibility provides:

A lawyer who receives information clearly establishing that:

(1) His client has, in the course of the representation, perpetrated a fraud upon a person or tribunal shall promptly call upon his client to rectify the same, and if his client refuses or is unable to do so, he shall reveal the fraud to the affected person or tribunal.

208. 266 F. Supp. 180 (S.D.N.Y. 1967).

209. Statement on Auditing Procedure No. 41, supra note 145.

210. AMerican Institute of Certified Public Accounts, Code of ProFESSIONAL ETHICS 16-17 (1971) (Interpretive Opinion No. 8). 
(2) A person other than his client has perpetrated a fraud upon a tribunal shall promptly reveal the fraud to the tribunal. ${ }^{211}$

The philosophy embodied in the Disciplinary Rule is supported by Disciplinary Rule 4-101(C), which makes it clear that the duty of a lawyer to preserve his client's confidences does not prevent an attorney from revealing "[c]onfidences or secrets when permitted under Disciplinary Rules ... [or] [t]he intention of his client to commit a crime and the information necessary to prevent the crime."212 Moreover, with respect to future illegalities, a footnote to Disciplinary Rule 4-101(C) ${ }^{213}$ points to a 1965 American Bar Association opinion" 214 for the view that "a lawyer must disclose . . . the confidences of his clients if 'the facts in the attorney's possession indicate beyond reasonable doubt that a crime will be cominitted." "215 When pondering the import of these Disciplinary Rules, two positions taken in the Code's Preliminary Statement should be borne in mind: first, the Disciplinary Rules "are mandatory in character;" and second, they state the "minimum level of conduct" demanded of an attorney in a given factual situation. ${ }^{210}$

It may further be noted that the ethical guidelimes regarding disclosure of clear illegality are of relatively recent origin. The view' that disclosure of prospective illegality is demanded does not seem to have been recognized prior to 1965, and Disciplinary Rule 7-102 (B) appears to make a clean break with the past view of an attorney's obligation to disclose his client's fraud. In 1953 the American Bar Association's Committee on Professional Ethics ruled, by a fivetwo vote, that an attorney who obtains a divorce for his client has no obligation to reveal his client's perjury regarding a vital element of the case. ${ }^{217}$ The majority felt that the lawyer's professional obligations were satisfied when le refused to furnish further assistance to the client. The position of the 1953 opinion was expressly re-

211. Code of Professional Responsibirity, supra note 16, Disciplinary Rule 7-102(B).

212. Id., Disciplinary Rule 4-101(C).

213. Id. at 18 n.16.

214. ABA Comm. on Professional Ethics, Opinion No. 314 (1965). The opinion provides in part that

the absolute duty not to make false assertions of fact [does not] require the disclosure of weakness in the client's case and in no event does it require disclosure of his confidences, unless the facts in the attorney's possession mdicate beyond reasonable doubt that a crime will be committed. Id.

215. Code of Professional Responsibitity, supra note 16 , at 18 n.16.

216. Id. at 2.

217. ABA Comm. on Professional Ethics, Opinion 287 (1953). 
jected by the draftsmen of 7-102(B). ${ }^{218}$

The BarChris decision holds that professionals should not be held to a standard of conduct higher than that existing in the profession. ${ }^{210}$ By its merger opinion claims the SEC appears to have used the Code of Professional Responsibility and the Fischer case to fashion its yardstick for measuring the legitimacy of the defendant attorneys' conduct under the securities laws. It is not easy to fault the Commission for that, absent some reliance on the argument that an attorney's responsibilities run solely to his client. And as has already been pointed out, the infirmities of that argument are that it fails to account for the essential similarity of audit certificates and legal opinions, it ignores the realities of stock market life, and it fails to recognize that the times have changed. It is probably fair to say that few lawyers appreciated the increased emphasis on public accountability manifested in the 1965 Opinion and Disciplinary Rule 7-102(B). The lesson of the National Student Marketing complaint is, as "Adam Smith" has warned us, "[W]e iguore revolutions at our peril." And as a profession it behooves us to bear in mind that "in every revolution the lawyers lead the way to the guillotine or the firing squad."220

\section{Opinion Letter Policies and Procedures}

Set forth in this section of the article is an outline of policies and procedures relative to the preparation of opinion letters. Like any collection of general guidelines, such as the accounting profession's Statements on Auditing Procedure which this outline is in part patterned after, the guidelines set forth below are interstitial in nature and will need to be modified to fit specific cases. Members of smaller firms may find some humor in the high degree of decentralization envisioned by the procedures, but it should be realized that regimentation is only a tool that may be used to insure that the legal opinion rendered is the product of thorough study and the exercise of independent judgment. While the utility of following sonie set of guidelines im. preparing opinion letters is readily evident in view of the National Student Marketing confrontation, it is equally clear that

218. Disciplinary Rule 7-102(B) cites the 1953 Opinion as suggesting a strongly contrary position.

219. 283 F. Supp. 643, 703 (S.D.N.Y. 1968). But see United States v. Simon, 425 F.2d 796, 805-06 (2d Cir. 1969), cert denied, 397 U.S. 1006 (1970) (holding that evidence of accountants' compliance with generally accepted accounting principles "may be highly persuasive, but not conclusive" as to appropriateness of an auditor's conduct).

220. F. Rodell, Woe Unto You, Lawyers! 17 (1957). 
a check list in itself never insulated anybody from hability. For real protection from a securities fraud or inalpractice claim there is no substitute for a professional attitude, professional ability, and professional know-how. ${ }^{221}$

\section{OPINION LETTER GUIDELINES}

\section{OPINION LETTERS AND OTHER DOCUMENTS COVERED:}
A. Opinion letters issued pursuant to agreements;
B. Opinion letters required by law or stock exchange regula- tion to be rendered in connection with the issuance or transfer of securities;

C. Opinion letters to be used in connection with seriously contested inatters, including litigation;

D. Audit letters;

E. Any other communications which inay reasonably be construed to express the opinion of the firm on points of law or judgment, and which may reasonably be relied on by third parties.

F. Any doubts as to whether a communication may be interpreted as expressing the opinion of the firm within the ineaning of these guidelines are to be resolvcd by either

221. This point was driven home most felicitously in a memorandum Louis Brandeis is reported to have written to himself on the subject of "what the practice of law includes." The memorandum reads in part:

Know thoroughly each fact .... Don't believe client witness. Examine documents. Reason; use imagination. Know bookkeeping-the universal language of busmess; know persons .... Know not only specific facts, but whole subject. Can't otherwise know the facts. Know not only those facts which bear on direct controversy but know all the facts and law that surround. Memorandun by Louis Brandeis, reprinted in THE GROWTH OF AMERICAN LAW, supra note 147, at 339.

Similar good counsel applicable to securities lawyers was given by one of the participants in the American Bar Association's National Institute on the BarCliris case:

No lawyer can be a decent lawyer in the securities field unless he can read and tear apart an income statement and a balance sheet; unless he understands the company and the industry in which he is participating in preparing the registration statement. I think that requires a visit to at least some of the counpany's offices and plants. I think it involves an understanding of the manufacturing process and the accounting system. I think it requires a lawyer who had the financial sophistication to handle his own investments. . . . It is important that [lawyers] know what an investment is and how the securities market works. There are too many lawyers who can read a book or analyze a case or establish nice legal distinctions but who haven't the foggiest idea about what an investor ought reasonably to know about a prospective investment. BarChris Institute, supra note 67, at 623-24 (reinarks of Graham L. Sterling, Jr.). 
treating the communication as an opinion in accordance with these guidelines or making clear in the text of the communication that it is not to be construed as an opinion of the firm on the matter considered.

\section{FACTUAL BASIS FOR ALL OPINIONS:}

A. The circumstances to be dealt with in any proposed opinion must be thoroughly examined, with the results of the examination documented in the file, before the opinion can be issued.

B. The following standards ${ }^{222}$ should be adhered to by persons conducting examinations preparatory to the issuance of an opinion:

1. The examination is to be performed by a lawyer having sufficient technical training to perform all phases of the task;

2. The lawyer making the examination is to maintain an independence in mental attitude in all matters relating to the management of the investigation;

222. Investigative standards $1-5$ are adapted from CoMmrtes on AudrTing Procedure of the American Institute of Certified Public Accountants, Statement on Audrting Procedure No. 33, Auditing Standards and ProCEDURE 15-16 (1963). Escott v. BarChris Constr. Corp., 283 F. Supp. 643 (S.D.N.Y. 1968), gives ample justification for the sixth requirement. In that case Judge McLean criticized the defendant attorney who had prepared the registration statement for not checking with his firm's bookkeeper to see if the bill for legal fees marked paid by BarChris had in fact been paid. The court said that "[i]f he [the attorney] had inquired and had found that this representation was untrue, this discovery might well have led him to a realization of the true state of BarChris' finances in May 1961." Id. at 692.

The legitimacy of a common sense approach in gauging the adequacy of investigation was emphasized by Milton V. Freeman when he discussed opinions dealing with pending litigation:

As to his prediction as to the outcome of specific litigation, if we could find somebody who would be regarded as an expert, he would have a fabulous career. Assuming that the lawyer has taken the trouble to pay some attention to what the complaint states and what the allegations are, and has made some research into the law, his conclusion will not subject him to liability even if it should turn out to be in error. BarChris Institute, supra note 67, at 676 (remarks of Milton V. Freeman).

See also Sommer \& Grienenberger, Summary of the Meeting Between Members of the Securities and Exchange Commission and Representatives of the Federal Regulation of the Securities Committee of the Section of Corporation, Banking and Business Law of the American Bar Association, Washington, D.C.-January 13, 1972, 27 Bus. LAw. 949, 950 (1972) (reporting a comment by then SEC Chairman Casey to the effect that a lawyer familiar with the history of the company and management could rely to a great extent on management's representations, but that there were many cases where facts needed to be independently verified). 
3. Due professional care is to be exercised in the performance of the exammation and the preparation of memoranda pertaining thereto;

4. The examination is to be supervised by the partner in charge;

5. By reason of the examination, sufficient competent evidential matter is to be obtained through inspection, observation, inquiries, confirmations and research to afford a reasonable basis for the opinion;

6. Before coinpleting the examination, contact should be made with lawyers who may have special knowledge about the facts being exammed, including the partner in charge of billing for the matter in question.

\section{ADEQUACY OF DISCLOSURE:223}

A. While it is recognized that the contents of opinion letters will vary under the circumstances, the opinion must at a minimum apprise the reader of:

1. The scope of the matters covered im the opinion; ${ }^{224}$

2. All material facts relied upon as verified by examination; ${ }^{225}$

223. See generally Statement on Auditing Procedure No. 33, supra note 222, at 54-55 (dealing with adequacy of informative disclosure).

224. With respect to opinions by counsel for underwriters, it has been noted that:

The form of the opinion relating to the registration statement is, in my judgment, of great importance from the standpoint of determining what responsibility counsel for the underwriters has assumed. This was the subject of comment by Judge McLean in BarChris in which he stated that the words of the opinion did not conform with the testimony given by the representative of the underwriters as to what they were relying upon counsel to do. BarChris Institute, supra note 67, at 654 (remarks of David S. Henkel).

225. The need for full disclosure of all relevant considerations pertaining to the subject matter of the opinion is strongly suggested by SEC Securities Act Release No. 4445 (Feb. 2, 1962). This is not to say that an opinion letter must reveal every conceivable tidbit of information bearing on the facts and investigation of them. The folly in trying for an all-mclusive approach was pointed out in connection with the use of legal opinions by underwriters to sustain their due diligence defense in a BarChris type situation:

MR. APPLEBAUM: We were asked for such an opinion by a midwestern based house that we did some work for. The opinion we ended up giving-I do not know whether you would call it an opinion or notlisted everything that the underwriter's own people had done by way of investigation and then everything that counsel had done; and then said that we could not think of anything else to be done, and that they had informed us that they could not think of anything else to be done, and that if there was not anything else to be done, then they had done everything that could be done. The next time we did an issue for that house, they did not request it! 
3. Any material facts relied upon which were not verified by examination and any qualifications of the opinion occasioned thereby; 220

4. Any circumstances bearing on the independence of the firm and its lawyers regarding the matter in question, including directorships and stock ownership positions held in a party involved in the matter; 227

5. The significant conclusions reached; and

6. For whose use the opinion is intended. ${ }^{228}$

B. Use of opinions prepared by other counsel: ${ }^{229}$

1. In the preparation of legal opinions reliance may be placed on opinions issued by other counsel only after satisfactory proof as to the professional reputation and independence of judgment of the other attorney. No reliance may be placed on another attorney's opinion when there exists substantial reason to doubt the conclusions stated therein.

2. If it is desired not to assume responsibility for the matters which are the subject of the other counsel's opmion, the opinion letter should make reference to the other opinion letter and should indicate clearly the division of responsibility for matters covered by the opinions.

C. Nothing contaimed herein prevents the disclaimer or qualification of an opinion. ${ }^{230}$

MR. MCDOWELL: At any rate it -seems to me that this kind of material in an opinion does not really help the due diligence defense very much. Officers' and Directors' Institute, supra note 18, at 136 (remarks of Alan Applebaum and Robert A. McDowell).

226. Cf. text accompanying notes 128-29 supra; Statement on Auditing ProCEDURE No. 33, supra note 222, at 63-69 (discussing the effects of circumstances that make it impracticable or impossible to verify matters by independent examination).

227. Cf. SEC Securities Act Release No. 5094 (Oct. 21, 1970) ("Guide Relating to the Interest of Counsel and Experts in the Registrant").

228. For example, soine firms serving as counsel in public offerings have adopted the policy of rendering two separate opinions to the underwriters. One covers such things as the incorporation of the issuer and the validity of the securities. It is intended for the benefit of the underwriters and purcliasers of the securities. The second opinion deals with the registration statement and it is intended solely for the use of the underwriter. See Officers' and Directors' responsibilities, supra note 18, at 135-36 (remarks of Robert A. McDowell); BarCliris Institute, supra note 67, at 654 (remarks of David S. Henkel).

229. See notes 128-29 supra and accompanying text.

230. See generally Statement on Audrting Procedure No. 33, supra note 222 , at 63 (discussing circumstances causing an auditor to qualify or disclaim an 


\section{REVIEW}

A. All opinion letters subject to these procedures should be reviewed by a partner able to make an evaluation of the soundness of the conclusions reached and their consistency with similar positions taken by the firm in comparable situations.

B. It is the responsibility of the partner in charge to insure that the name of the reviewing partner and the scope of the review are noted in the file.

\section{SIGNATURE:}

Only partners are authorized to sign the firm name to opinion letters covered by these provisions. The only exception to this restriction is that, after an opinion has been examined by the reviewing partner and prepared in final form, the partner in charge may specifically authorize an associate to sign the firm's name to the document.

\section{PARTICIPATION IN TRANSACTION:}

Lawyers may not participate as investors in any transaction for which the firm issues an opinion letter. ${ }^{231}$

\section{SUBSEQUENT EVENTS:}

If, subsequent to the date of issuance of any opinion letter, it becoines apparent that circumstances inay have existed at that date which might have had a significant effect on the opinion had such facts been known, then it should be considered whether there are persons currently relying on or likely to rely on the

opinion). The SEC apparently recognizes that "it is quite appropriate in some circumstances to state that counsel expresses no opinion on the merits or probable outcome of ... litigation." Sommer \& Grienenberger, supra note 222, at 950. The threat of either tipping a client's hand as to the existence of a contingent liability or being less than candid with an inquiring accountant has led some firms to adopt the practice of refusing to render opinions as to clients' contingent liabilities. Address of Francis M. Wheat, supra note 85.

231. See note 202 supra and accompanying text. There is some question whether lawyers should own stock in a client at all. The logic belind a rule banning stock ownership was discussed by members of a panel of securities lawyers at the 1972 New York Law Journal Conference on lawyers' expanding responsibilities:

MR. FLOM: [B]asically our firm is against owning stock in clients.

In no sinall measure because whatever you do, you have to be wrong.

If you own stock and the client is relatively small, if you sell and

the stock goes up, you feel stupid. And if you sell and the stock goes down, everybody accuses you of trading on inside information.

MR. SOMMER: If you sell at all under any circuinstances your client will think you lost faith in him and be aggrieved over that. I think that's a very tough problem. TRANSCRIPT, supra note 14 , at 174 . 
opinion who would attach importance to the subsequently discovered information. If, after weighing various pertinent factors, including the time elapsed since the opinion was given, it becomes apparent that action should be taken to prevent future reliance on the opinion, appropriate steps slould be taken to make disclosure of the newly discovered facts and their opinion to persons who are known to be currently relying on, or who are likely to rely on the opimion. The inethod of notification slould be the best practicable under the circumstances, and may include notification of pertinent regulatory agencies. ${ }^{232}$

\section{CoNCLUSION}

There is an admonition in the Book of Luke that reads: "Alas for you lawyers . . . because you load on men burdens that are unendurable, burdens that you yourselves do not move a finger to lift."233 The SEC's cliarges against the defendant attorneys in the National Student Marketing case undermine the validity of that cominent. To be sure, the SEC's theme portends a future filled with hard clioices for business lawyers, but is not the pressure of choice mherent in the legal calling? What is the lawyer's stock in trade if it is not the exercise of studied judgment?

Whatever the ultimate outcoine of the National Student Marketing hitigation, the case will very likely be seen in retrospect as liaving had at least one salutary effect. Spurred by the Commission's unprecedented charges, the corporate bar has already begun to engage in a self-analysis that promises to yield an articulation of more visible and cogent standards to govern professional conduct. This development will surely redound to the inutual benefit of the bar and the people it serves, and it is by evoking from the bar a firm commitment to the principle of professional self-regulation that the National Student Marketing case promises to enrich the practice of corporate law.

232. See notes $143-46$ supra and accompanying text.

233. Luke 11:46 (Jerusalem Bible). As the general counsel for a major accounting firm has noted:

Recent complaints filed against lawyers have generated cries of anguish about damaged reputation. In the past, when other professional groups poimted out that the mere filing of a complaint without more can be very damaging to reputation, their lamentations fell largely on deaf ears. Now that lawyers are also targets-indeed, ripe targets according to the apparent consensus of this panel-perhaps they will reevaluate their function in drafting complaints against other lawyers and other professionals. I am not suggesting that they should desist from bringing such actions; I am suggesting that they should look once again at the letter and spirit of Rule 11 of the Federal Rules of Civil Procedure, which has for too long been honored in the breach. TransCrIPT, supra note 14, at 250 (remarks of Victor M. Earle, III). 
